\title{
The Use and Management of Medicinal Plant by Shenasha People in Dibati District North West Ethiopia
}

\author{
Abesh Birhanu Morka ${ }^{1, *}$, Tena Regassa Duressa ${ }^{2}$ \\ ${ }^{1}$ Ethiopia Biodiversity Institution, Mettu Biodiversity Center, Forest and Range Land Plant Biodiversity Case Team, Mettu, Ethiopia \\ ${ }^{2}$ Department of Biology, Faculty of Natural and Computational Sciences, Wollega University, Nekemete, Ethiopia \\ Email adders \\ birhanuabesh12@gmail.com (A. B. Morka), tenaregasa@gmail.com (T. R. Duressa) \\ ${ }^{*}$ Corresponding author
}

To cite this article:

Abesh Birhanu Morka, Tena Regassa Duressa. The Use and Management of Medicinal Plant by Shenasha People in Dibati District North West Ethiopia. Journal of Diseases and Medicinal Plants. Vol. 7, No. 3, 2021, pp. 61-81. doi: 10.11648/j.jdmp.20210703.12

Received: June 30, 2021; Accepted: July 28, 2021; Published: August 23, 2021

\begin{abstract}
Traditional medicinal plant species documentation is very crucial in Ethiopia for biodiversity conservation, bioactive chemical extractions and indigenous knowledge retention. An ethnobotanical study of the indigenes knowledge on medicinal plants by shinasha people in Dibati District, Northwest, Ethiopia, was conducted from October 2017 to Nomber 2017. This study therefore, aimed at documenting indigenous knowledge on ethobotanical use of medicinal plants by herbalists to treat human and livestock ailments as well as assessing of the existing threats to these medicinal plants in Dibati district. Ethnobotanical data were obtained using semi structured interviews, field observations, focus group discussions with people and traditional medicine practitioners and various ranking and comparison methods were employed. Data were analyzed quantitatively and by Microsoft office excels informant's preference ranking, descriptive statistic Direct matrix ranking, paired comparisons, fidelity value index and Informant consensus factor (ICF) are computed to assess the degree of effectiveness of certain medicinal plants against human and animal. Information was collected from a sample of 99 informants (77 males and 22 Females) included 20 (male 16 female 4) key informants are selected to the help of kebele administration. Ethnomedicinal use of 65 plant species from in 62 genera and 39 families were documented. In terms of number of species, Febaceae appeared as the most dominate family that Contains 7 species in 7 genera, followed by Asteraceae. From the total medicinal plant species, $24(2461.9 .7 \%)$ were herbs, followed by $18(27.69 \%)$ species of trees. The most frequently used plant parts were leaves (28.06\%) followed by roots (14.06\%). The most widely used method of preparation was crashed (23.07\%), Pounding (20). The common route medicine administration were oral $(54.4 \%)$, followed by dermal $(7.69 \%)$ and other. The most commonly used application of medicinal plant was drinking (35.38\%) followed by smoking (18.64\%). A total of 65 plant species 48 (73.84.\%) species were mentioned for the treatment of 57 human ailments while 17 (26.15) species were used to treat 15 livestock health problems. In the study area possesses diverse natural vegetation and the environment under serious threated by mainly agricultural expansion, firewood collection, population pressure, overgrazing, urbanization, household tool construction, charcoal production and medicinal purpose. Awareness rising on the use and management systems, sustainable utilization of medicinal plants and their in-situ and ex-situ conservation and establishment of forest protected areas should be recommended.
\end{abstract}

Keywords: Medicinal Plant, Dibati Woreda, Informant, Shinasha People, Ethnobotanical, Fidelity Level Index (FLI), Informant Consensus Factor (ICF)

\section{Introduction}

Traditional medicinal plant species documentation is very crucial in Ethiopia for biodiversity conservation, bioactive chemical extractions and indigenous knowledge retention. In all part of the world traditional medicinal plant practices formed the basis of health cares for both human being and animal before the advent of modern medicine. In the Ethiopia people have been using traditional medicine to treat both human and animal disease for generations. Traditional medicine is still wildly practices in rural area where modern medicine and services available [29]. Traditional medicinal plants are also used for various purpose in additional their 
medicinal values such as a forage, firewood, spics, construction, food, cosmetics, clothes, shelter for human habitats for wild animals and insects. Maintaining ecosystem stability export accommodation and fumigant [15]. Traditional herbal remedies can also be used as scientific resources to develop a new drug which are safes. It is also effectively cheapest and environmental sounds. Many of today's wonderful drugs were initially discovered through the study of traditional medicine [29]. (There are large number of moderate to high value of medicinal plants herbs and species existing in the world. However, of the existing medicinal herbs species only small percent are treaded. Availability of medicinal plant has been affected $[10,15]$. by a dramatic decrease of native vegetation due to agricultural explanation, deforestation, fire, and overgrazing drought, tread of charcoal, firewood, introduction of alien invasive species and urban associated development. Globally the estimates of medicinal plant species range from 35,000-50,000 and out of this about 4,000-6,000 species have entered the world market of medicinal plants. The knowledge about the use of plants is largely oral; however, Plantations of medicinal plants can be made in degraded and degrading areas. There are many medicinal plants of Ethiopia that have good properties for land rehabilitation and erosion control which could be planted in different agro ecological settings. In-situ and exsitu conservation strategies work well when they complement one another since what is not achievable by one method is backed by the other method. In addition to this scheme that would enable sustainable use of medicinal plants and the associated indigenous knowledge should be developed with the best practice of benefit sharing [10]. Maintain health through traditional medicine in general and utilization of medicinal plant in particular is almost as old as the history of man kinds. This is true in Ethiopia $80 \%$ of the population still relies on the plant to prevent and cure various health problem [15].

The current plant use trend in Dibati district shows that the environment is facing problems of resource depletion and loss of indigenous knowledge like other areas of the country. Thus, intensive ethnobotanical research plays a vital role to draw information on plants and related indigenous knowledge for conservation and sustainable utilization. Like many other parts of the country, there is no such ethno medicinal research and documentation carried out in Dibati District, Metekele Zone, Northwest and Benshangul Gumuz Region. In this woreda there is no any research which is done on the use and management of medicinal plants in the Shinasha peoples.

\section{Materials and Methods}

\subsection{Study Area}

The research was conducted at Dibati district particularly which is found in Metekele zone, Benshangule Gumuze Regional State that is found at $586 \mathrm{~km}$ northern west of Addis Ababa, the capital City of Ethiopia. The Benishangul Gumuz Regional State (BGRS) was established in 1994 as one of the nine regional states of Ethiopia. The BGRS borders the Republic of Sudan in the west, Amhara region in the North, Oromiya in the South east and Gambella region in the South. Administratively, it is divided in to 3 zones (Metekele, Assosa, and Kemashi) that are divided in to 19 Woreda, and one special Woreda. Metekel Zone is divided into 7 Woreda out of which Dibatie Woreda, the study area is located North 100 55'-110 90' latitude North and 300 12'-300 36' longitude East. (Source BGRS, 2008).

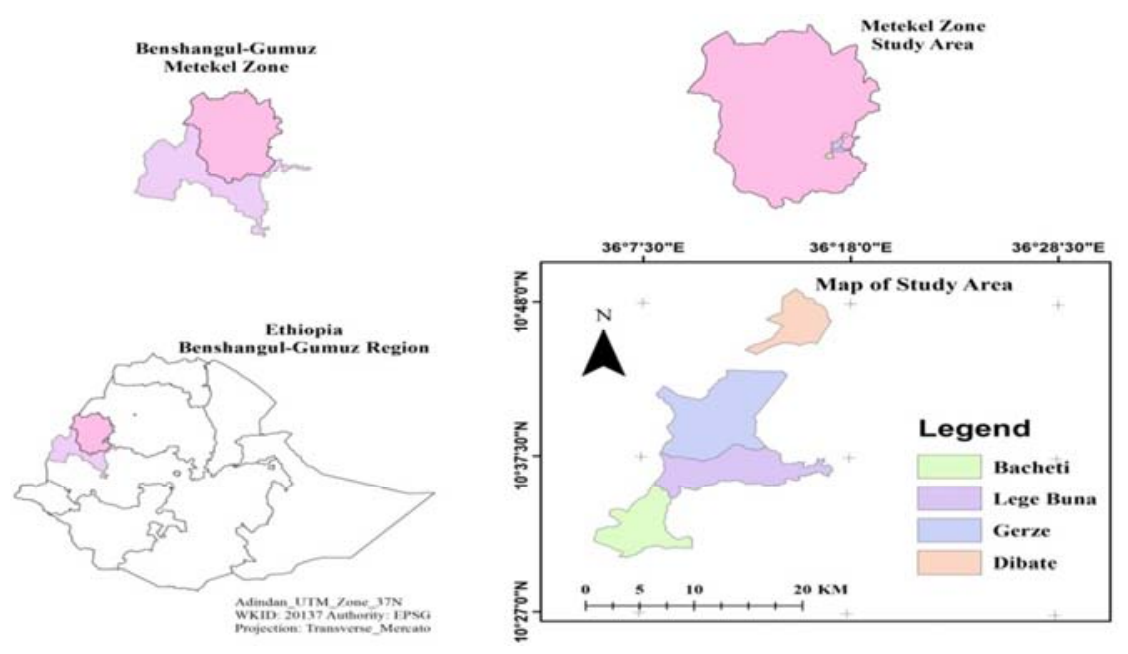

Figure 1. Maps of study area.

Based on the central statistics data (CSA, 2007), the total population for this Woreda of 66,654 , of whom 33,452 were men and 33,202 were women; 7,399 or $11.1 \%$ of its population were urban dwellers of all 12,446 were children's. The vegetation of the study district is predominantly composed of different woody and herbaceous species. The natural vegetation of Dibate is mainly composed of various lowland and midland species such as Acacia sp., Ficus spp. (Such as Ficusthonnigi, Ficussur, Ficus vasta, Ficusmochsttery, e.t.c., Cordia africana, Albizia spp. Coroton 
macrostachyus, Adonsoniadigitata, Dombeya spp., Ekeverglacapensis, Carissa, Sizigum spp., and other trees, shrub and herbaceous species

\subsection{Study Design}

\subsubsection{Reconnaissance Survey and Selection of Study Sites}

Dibati Woreda has a total of 29 kebeles. Out of these, 5 kebeles was selected those are Modorem, Gerze, Zegehe, Legbuna, and Bechati due to the have high amount of shinasha peoples found in kebele. Additional to that they have larger vegetation cover and presence of key informants, different altitudinal ranges are selects for ethnobotanical data collection. The traditional healer, used as key informants, was identified by with the assistance of local authorities, elders and knowledgeable persons.

\subsubsection{Informant Selection}

Information regarding to each peasant association leaders the total household of Shenasha people in the study area of five kebele from the age of tewenty and above is $(\mathrm{N})$ is male 651 female 141 total 792. To obtain total sample size from the total targeted household, the researcher was use the usual known formula. (Yemane, 1967) that were calculated as follows:

$$
\mathrm{n}=\frac{N}{1+N(e)^{2}}
$$

Where $\mathrm{n}$ is sample size of the study area

$\mathrm{N}$ is targeted population size (total population of five kebele in study area.)

e: is the level of precision or sampling error $=(0.05)$

For the above formula,

$$
\mathrm{n}=\frac{792}{1+792(0.05)^{2}}=99
$$

A total 99 informants five to seven individuals from each study kebele from the age of tewenty and above were included. From the five studies kebele twenty key informants were purposively selected based on recommendations from local authorities (kebele administrators and local guides) peasant association leaders and other members of the local communities.

\subsubsection{Plant Specimen Collection and Identification}

At the end of the interview, the reported medicinal plants were collected from natural vegetation and home garden. Sample specimens of the plants cited for their medicinal use was collected, numbered, pressed and dried for identification. Plant identification was performed both in the field, and at the National Herbarium of AAU. Preliminary identification was done in the field and reconfirmed at the National Herbarium. The identification of other plant specimens using the Flora of Ethiopia and Eritrea also by comparison with authenticated specimens.

\subsection{Ethnobotanical Data Collection}

Ethnobotanical data was collected between Octobers to November, 2017 on three field trips. The data was collected based on prepared questionnaires, semi-structured interviewees, observation, focus group discussion, and guided field walks with informants were employed to obtain indigenous knowledge of the local community of shinasha people. The study was carried out by interview in there habitants in different village. The informants include the various data sets such as local names, disease treated, parts of the plant used, and method of preparation dose and rote of application was obtained from local people through individual interviews. A list of question was prepared that covers the discussion with the informants in particular orders. All of the interviews will be held in Amharic and Shinasha language of the local people. The place and time for discussion were set based on the interest of the informants [5].

\subsection{Ethnobotanical Data Analysis}

The Ethnobotanical data collected was analyzed following survey and analytical tools for ethnobotanical methods which are Informant's preference ranking, descriptive statistic (Microsoft excel spreadsheets soft wore), Direct matrix ranking and paired comparisons conducted following [20,5]. Were computed to assess the degree of effectiveness of certain medicinal plants against human and animal.

\subsubsection{Medicinal Use Value}

The use value (UV), a quantitative method that demonstrates the relative importance of species known locally [19]. Was calculated using the following formula. UV $=\Sigma \mathrm{U} / \mathrm{n}$ where: $\mathrm{UV}=$ use value of a species; $\mathrm{U}=$ number of citations per species; $\mathrm{n}=$ number of informants

\subsubsection{Fidelity Level Index}

Fidelity level index quantify the importance of a given species for a particular purpose in a given cultural group[8]. The relative healing potential of individual medicinal plants used against human or livestock ailments using an index called Fidelity Level Index (FLI) based on the proportion of informants who agreed on the use of a given medicinal plant against a given ailment category.

The formula for FL is given as FL\% = Ip / Iu X 100, where Ip the number of informants who independently indicated the use of a species for the same major ailments and Iu the total number of informants who mentioned the plant for any major ailment (Friedman et al., 1986).

\subsubsection{Informant Consensus Factor}

Informant consensus factor (ICF) was calculated for categories of ailments to identify the agreements of the informants on the reported cures using the formula used by $[19,22]$. ICF was calculated as follows: number of use citations for each ailment (nur) minus the number of species used (nt) for that ailment, divided by the number of use citations for each ailment minus one (Table 7).

$$
\mathrm{ICF}=\text { nur_nt } / \text { nur_1 }
$$

Where:

ICF: Informant consensus Factor,

Nur: number of use citation 
$\mathrm{Nt}$ : number of species used

\section{Results and Discussion}

\subsection{Ethnomedicinal Plant Species Used by Shinasha People in Study Area}

In the study area a total of 65 medicinal plant species 62 genera and 39 families were gathered and documented that are used for the treatment of human and livestock ailments. From these, 48(73.8\%) species were used as human medicine, 1 species only $(1.54 \%)$ as livestock medicine and the remaining 16 species $(24.62 \%)$ were used for treating both human and livestock ailments (seen in figure 3). Of these 65 medicinal plants studied, 48 species were gathered from the wild and 17 species from home garden. This result indicates that the local communities mostly depend more on medicinal plants collected from the wild than those from home garden.

In my result family distribution, Fabaceae stood first dominant 7 (10.76\%) followed by Asteraceae, Euphorbiaceae and Cucuribitaceae four $(6.13 \%)$ species and next family, Combretaceae three species and other families consist of one representative species in each (appendix XI) This agrees with the finding of [16-18, 11, 12, 23, 24, 7, 4].

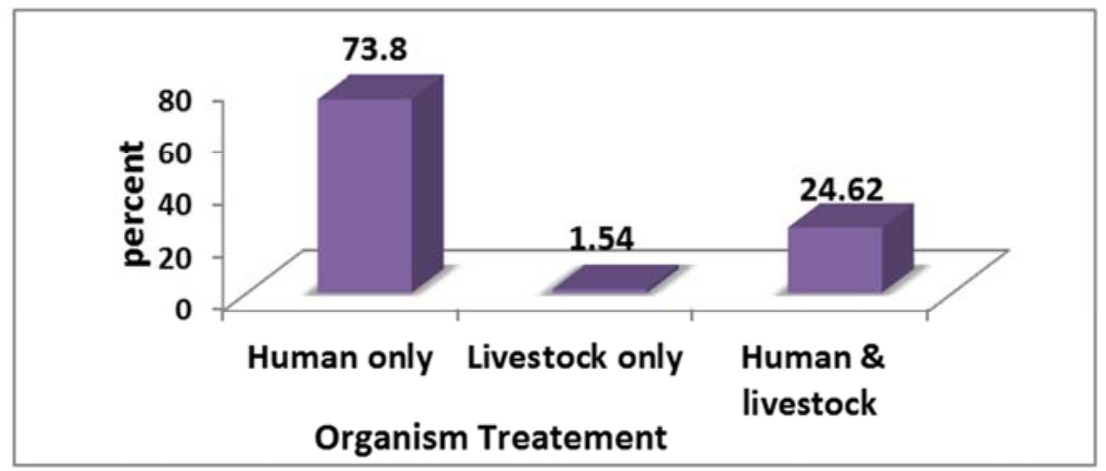

Figure 2. Proportion of medicinal plants used to treat human, livestock and both human and livestock ailment.

\subsection{Medicinal Plant Habit, Habitat, Part(s) Used and Preparation Rout of Administration Both in Human and Livestock Ailments}

\subsubsection{Habit of Medicinal Plant in the Study Area}

In the study area there are many habits of medicinal plant those are herb, shrub, tree and climber. The result shows that analysis of growth forms of medicinal plants revealed that herbs constitute the largest category $24(36.9 \%)$ followed by tree $18(27.69 \%), 16(24.61 \%)$ shrub and $7(10.76 \%)$
Climbers were recorded. The record of the highest number of herbs medicinal plant species in the study could be dominated. This may be due to their relative better abundance, accessibility in nearby areas as compared to other life forms, there is presence bimodal rainfall and extended availability of moisture and herbs can grow everywhere compar toother plant habits. This Habit distribution of medicinal plants has also been reported by some researchers previously [5-7, 24, 22, 13, 27].

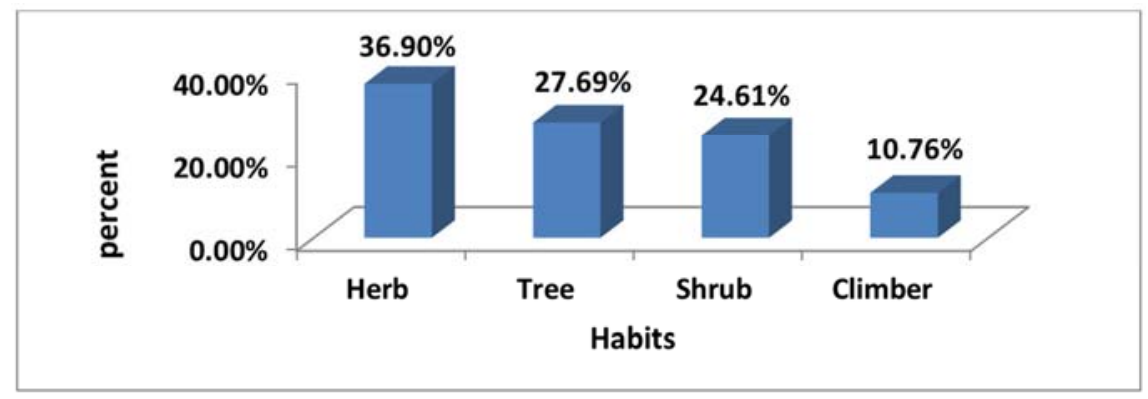

Figure 3. Habit of medicinal plants both human and livestock ailment in the Dibati woreda.

\subsubsection{Habitats and Abundance of Medicinal Plants in the Study Area}

In this study area medicinal plants were collected from various habitats including wild and home garden. As the result shows that most of the medicinal plants used by the communities were collected from wild 48(73.86\%) and Home garden $17(26.15 \%)$. This finding is similar to the general pattern seen in most medicinal inventories for example, [16, 11, 1, 28, 26, 36, 24, 21]. where wild medicinal plants dominate. The local people cultivate some popular medicinal plants in their home garden for the purpose of medicine such as Allium sativum, Schinus molle, Ocimum lamiifolium, Rhamnus prinoides and Nicotiana tabacum.

This and field observation during data collection clearly confirmed that some traditional healers do not have interest to grow in their home garden some plant species that are used 
to treat specific ailments in order to keep the secret of their medicinal value. This means that most of the medicinal plants found in the home gardens are those also known to have other uses particularly as food.

\subsection{Medicinal Plants Parts Used Treatment Both Human and Livestock in the Study Area}

The most widely used plant part for the preparations of remedy were leaves, which accounted for $28.06 \%$ followed by roots $(14.06 \%)$, seed $(10.39 \%)$ break $(9.39 \%)$ bulb $(6.25)$ and others. In this study, leaves are the most frequently utilized part of plant organs. it was ease of accessibility to leaves explains their frequent inclusion in most of the preparations. It was also observed that residents have been using leaves to identify. Additionally, leaves are the main photosynthetic organs in plants, and photosynthetic are translocate to other parts, such as the root, stem, fruit, and seed. These can act as toxins for protection of predators and some are of medicinal value to humans.

Within my finding, similar studies agreement to in other parts of Ethiopia reported and documented that leaf are the most commonly used medicinal plant parts followed by root $[23,5,1,13,24,14,7,26,28]$.

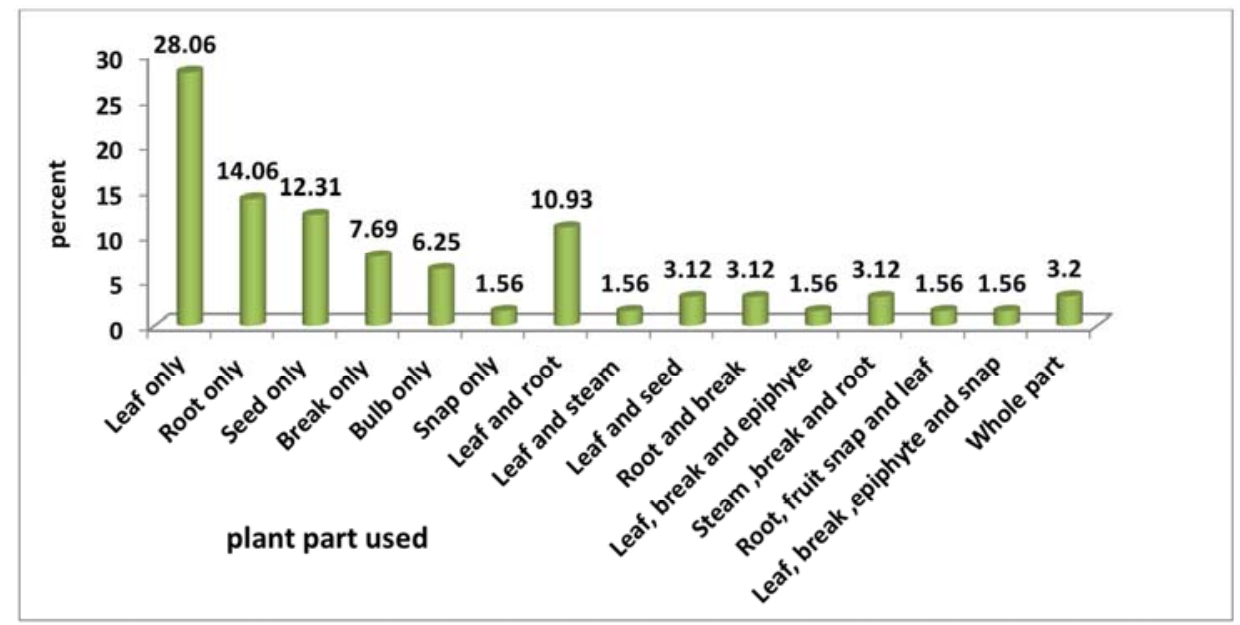

Figure 4. Plant Parts used in preparation of both human and livestock ailments in the study area.

\subsection{Method of Preparation}

The result that shows the preparation of medicinal plant for human and livestock of local community employs various methods of preparation of traditional medicines for different types of ailments. The preparations vary based on the type of disease treated and the actual site of the ailment. The principal methods of plant parts remedy preparation forms were reported to be through crushed, which accounts for
$15(23.07 \%)$, followed by pounded $13(20 \%)$, squeezing $10(15.4 \%)$, chewing $7(10.71 \%)$, crashing and pounded $5(7.7 \%)$, cocking $4(6.15 \%)$, eating $3(4.61 \%)$, smoke/burning $3(4.61 \%)$ crushed squeezed $2(3.07 \%)$, pounded squeezed $2(3.07 \%)$ and pounding powder $1(1.5 \%)$ respectively. The most dominate method of preparation is crushed. In agreement with this study, similar researcher of medicinal plant species method of preparation are reported from different parts of the country by $[14,27,7,36]$.

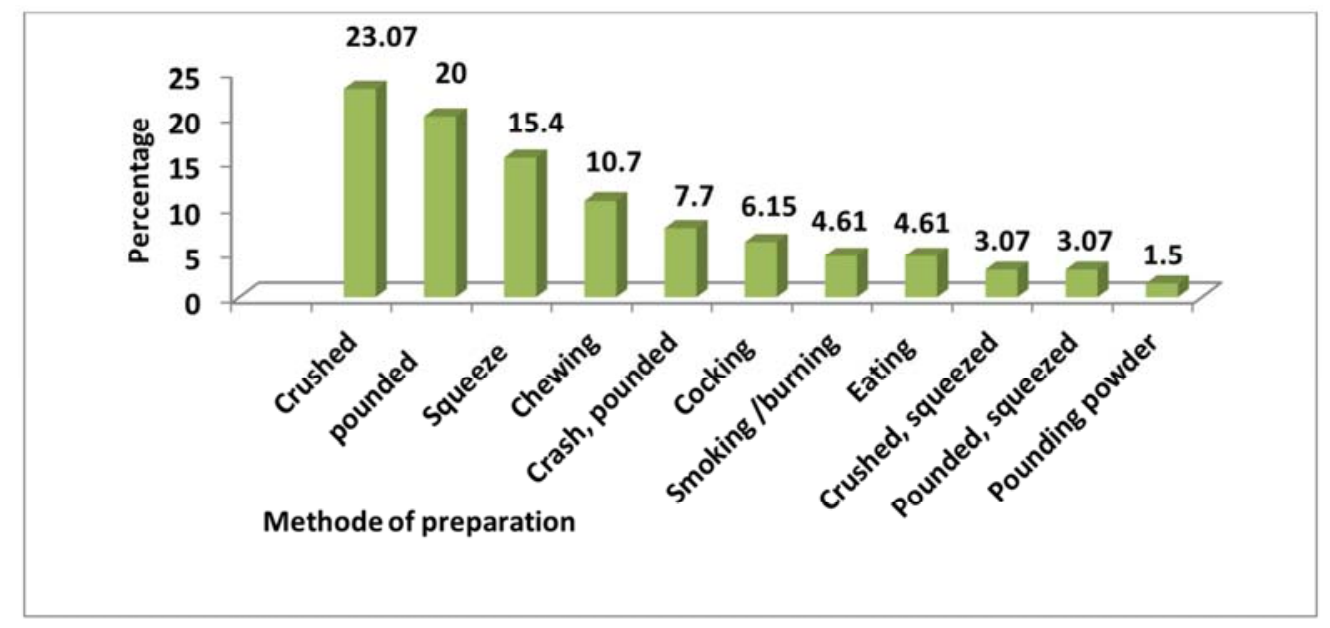

Figure 5. Preparation methods both in human and livestock ailments in the study area. 


\subsection{Route of Administration}

The major routes of administration in the study area are oral, dermal, nasal, anal, tide; ear and fumigated. People of the study area mostly administer traditional medicine orally. Oral accounts $38(58.46 \%)$ followed by dermal $5(7.69 \%)$, oral and dermal $6(9.23 \%)$ and others (Figure 8$)$. Due to they may indicated the higher prevalence of internal ailments in the study area.
However, the dose should be given in great care in the oral system than in the dermal since it might cause other severe internal problems. Similarly, various research findings mentioned oral application as the primary route of administration in traditional plant medicines. This fact that has been documented by different authors in the other part of Ethiopia. [2, 5, 12-14, 4, 7, 36, 25].

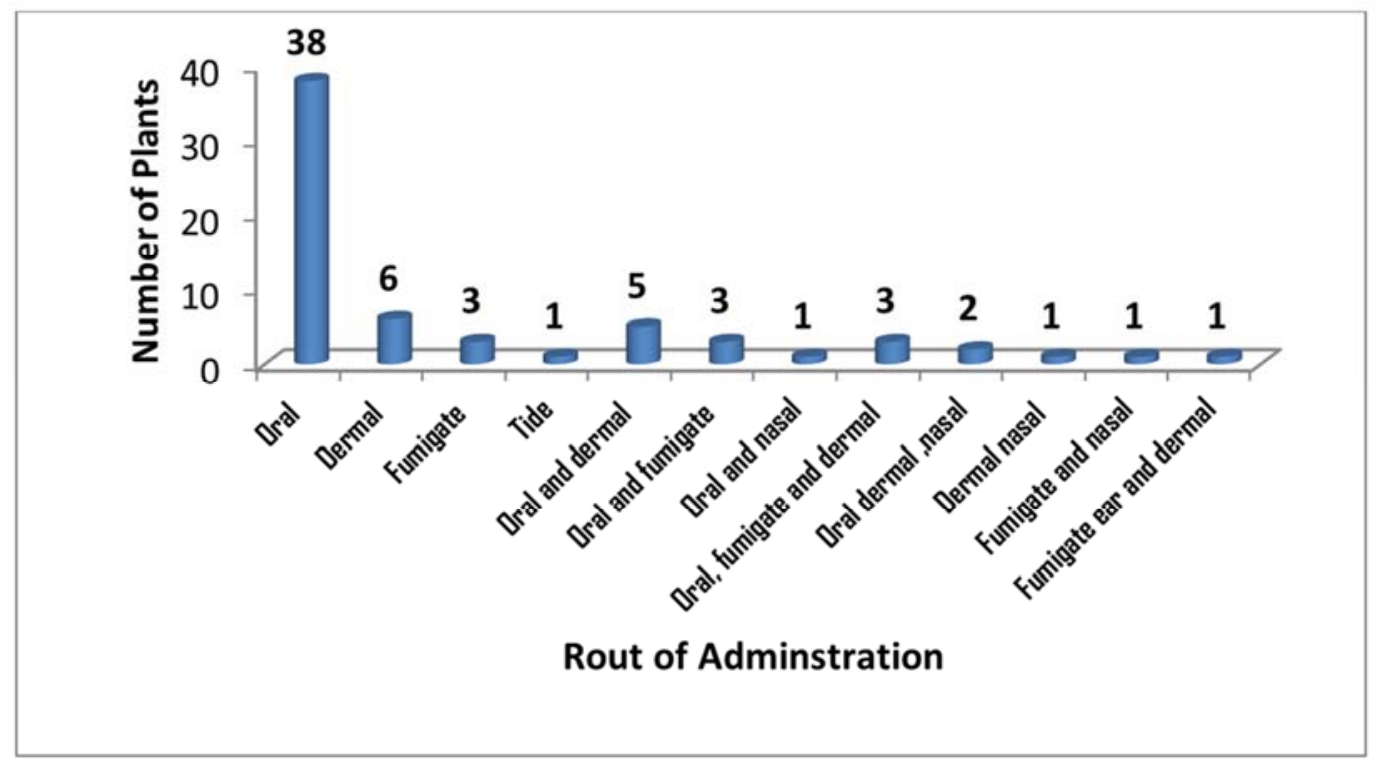

Figure 6. Route of administration both in human and livestock ailments in the study area.

\subsection{Application}

The prepared traditional medicines are applied in a number of methods, drinking accounted for the largest $23(35.38 \%)$, followed smoking $11(16.76 \%)$ creamed and snaffid $7(10.76 \%)$ and others (Figure 6). Internal ailments were commonly treated by making the patient drink herbal preparations; tooth infection were treated by crushing and put on the remedial plant part on the tooth surface; skin infections such as ringworm were treated by painting herbal preparations on an infected skin. Some plants do have different applications for different disease types. This preparation is used for different diseases by diverse application techniques. For instance, putting the leaves on tooth surface is used to cure toothache, and to tie on swollen body part is used to cure swelling. Similar results were reported elsewhere in Ethiopia by $[6,18$, $9,11,23]$.

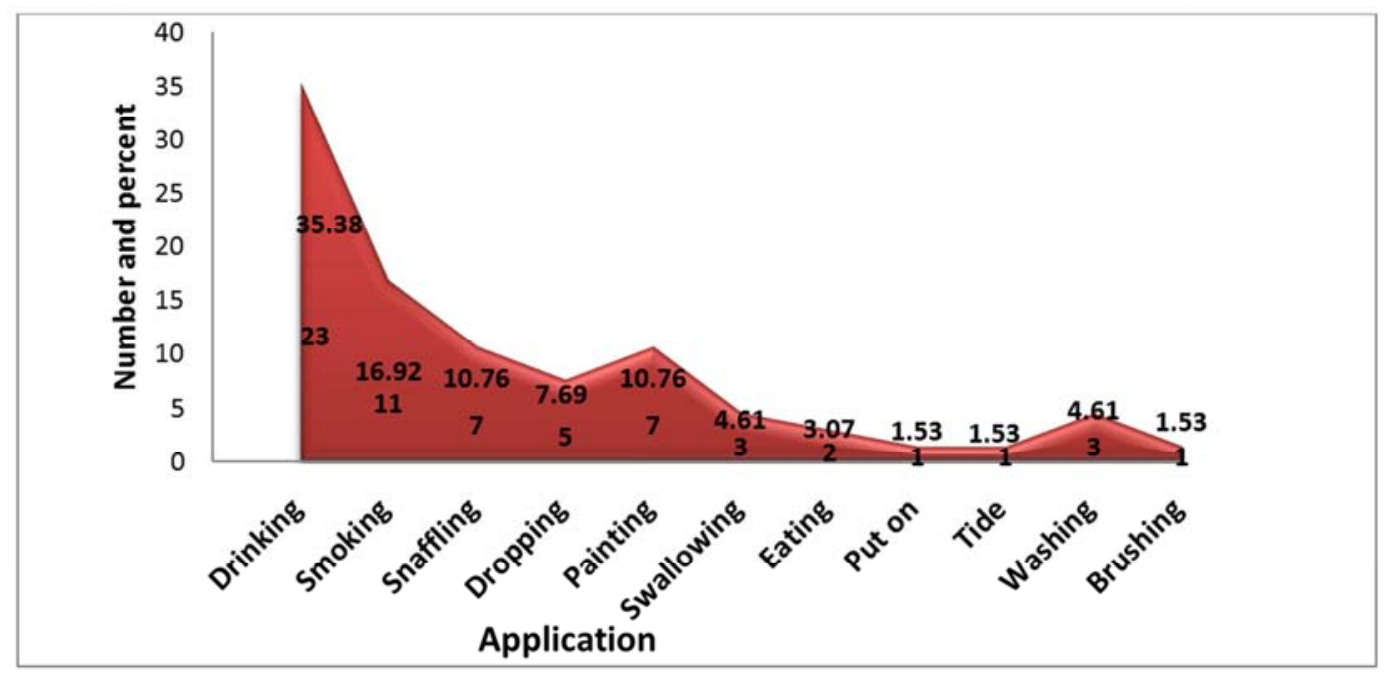

Figure 7. Graph showing ways of application of plant remedies in both human and livestock ailment treatment. 


\subsection{Conditions of Preparation of Herbal Remedies}

The results showed that herbal remedies are prepared using fresh material $45(69 \%)$, while $8(12 \%)$ were used in the case of dried plant material and $21(18.46 \%)$ in both condition. (Figure 7). The informants in the study area prefer fresh plant materials $(69 \%)$ to prepare effective and efficient remedies due to the fact that, most of the bioactive phytochemicals are retained in fresh plant materials as compared to dry ones. Although frequent collection of fresh plant materials in dry seasons has a devastating influence on the conservation statuses of medicinal plants, it is common to use fresh plant materials for the preparation of remedy. In addition to that they believe that using fresh materials increases efficacy compared with the dry one. This is because of the fact that the content or ingredients may be lost or reduced when the plants became dry. Similarly, various studies in Ethiopia has reported by $[33,22,17,12,30,32,15,13,1,24,36,7,26]$.

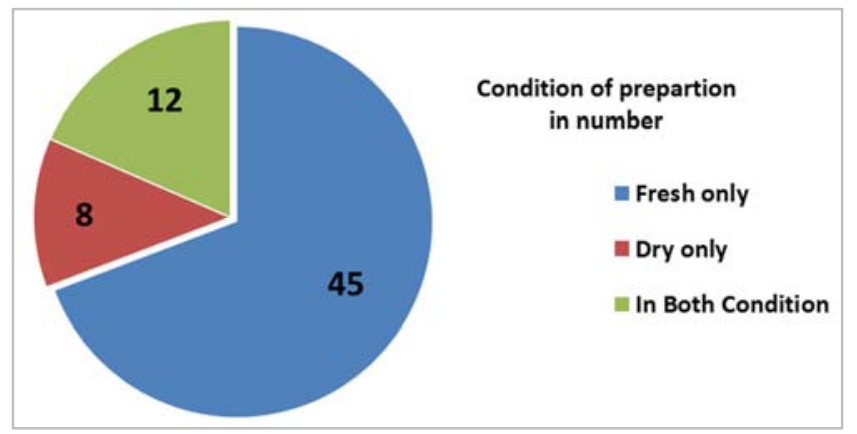

Figure 8. Conditions of Preparation both in human and livestock ailments.

Table 1. Solvents and additives used in medicinal preparation.

\begin{tabular}{lll}
\hline Solvents and additives & No- of informants who cited the species & Percent (\%) \\
\hline Water & 85 & 85.8 \\
Honey & 73 & 75.76 \\
Better & 61 & 61.6 \\
Milk & 59 & 59.5 \\
Sugar(tea) & 42 & 42.4 \\
Tefee powder & 31 & 31.3 \\
Hen wote & 29 & 29.2 \\
hyena liver & 18 & 18.1 \\
Coffee powder & 15 & 15.1 \\
Bordee & 14 & 14.1 \\
Meat & 13 & 13.1 \\
\hline
\end{tabular}

\subsection{Solvents and Additives}

Some of the remedies are taken with different additive and solvents, the solvent used is water. The additives include butter, honey, milk, sugar, 'teff' flour, boiled coffee or tea, hen wote, hyena liver, bordee and meat (Table 1). These additives have importance in reduction of pain, to get better taste and reduce adverse effects such as vomiting and diarrhea and enhance the efficacy and healing conditions as explained by informants.

For exampe, the seed of Coffea arabica is roasted crushed powdered boil and the filter one cup of tea, mixed with afew drop of oil then drink for treatment of diarrhea. The roots Justicia schimperiana is crashed pouded and mixed with the honey and drink one glass for 3-5 days for treatment of stabbing pain. The who part Clematis hirsuta is pounded powder and mixed with butter and creamed affected part until recover for 5 days to treat wound.

\subsection{Sources and Transferring of Indigenous Knowledge}

\subsubsection{Sources of Traditional Knowledge Practices}

The highest number of traditional medicinal plant knowledge gain from to be $45(45.4 \%)$ Father followed by $20(2.02 \%)$ form Mother and $15(15.1 \%)$ form Uncle $10(10.1 \%)$ from Brother, 8(8.08\%) from Sister 6(6.06) from Neighborhood and 5(5.05\%) form Friend. The great majority of respondents $(90 \%)$ reported that most of their knowledge was received from their family members and friends secretly by oral. The secret practices of traditional medicines came from their ancestors. Within my finding similar studies are agreed by $[31,28,36,14,27]$.

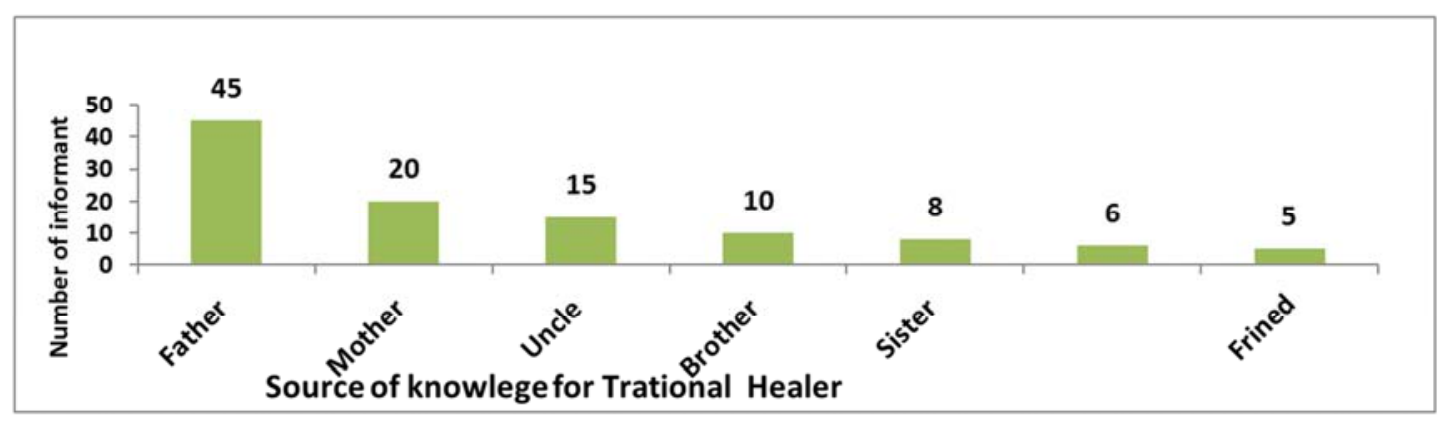

Figure 9. Sources of knowledge on the practice of traditional medicine. 


\subsubsection{Transferring Knowledge of Traditional Medicinal Plants}

According to the survey, knowledge transfer of medicinal plants follows vertical transfer to the most selected family member orally with great secrecy. The findings of the study showed that as people become older and older their knowledge of traditional medicine becomes better and better. Most of the informants were elders that indicated the trend of transferring knowledge is usually at old age. The highest number for the ways of transferring knowledge on traditional medicinal plants by elder son who received 56(56.5\%) votes followed by the elder daughter $12(12.1 \%)$, for the brother $10(10.1 \%)$ for the sister $7(7.07 \%)$ for the not to all $5(5.05 \%)$ for all went to known $4(4.04 \%)$ to all the member of my family $3(3.03 \%)$ and other to fried 2(2.02\%) (Figure 10). Therefore most way of indigenous knowledge transfer in the study District was by word of mouth to a family member (especially to an elder son). Similar findings were reported for other communities in Ethiopia [28, 27, 36].

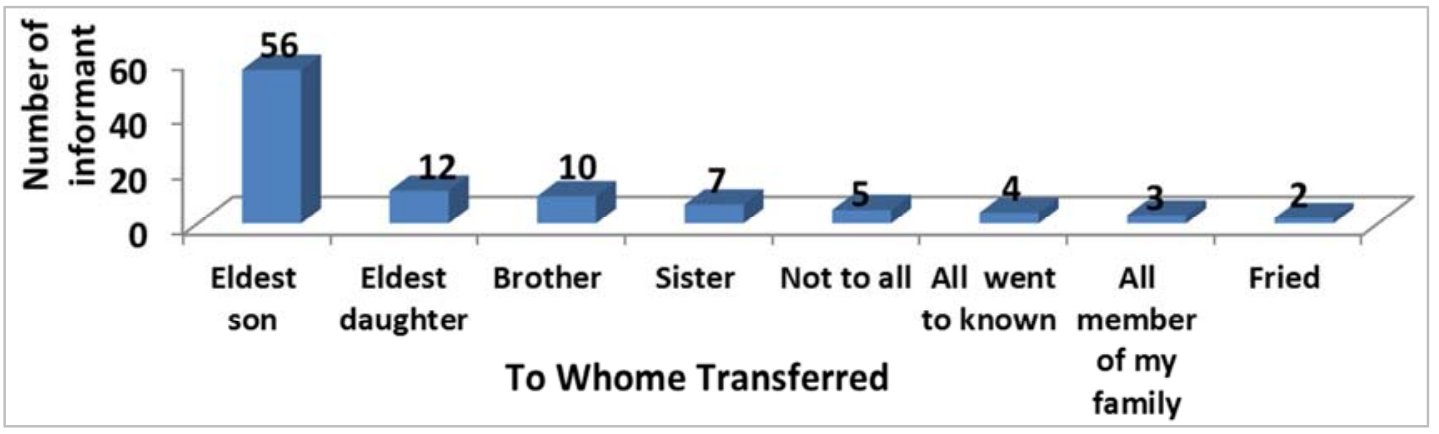

Figure 10. Transferring of knowledge of traditional medicinal plants.

\subsection{Ranking of Most Important Medicinal Plants}

\subsubsection{Preference Ranking}

Preference ranking for eleven medicinal plants to treat snake biting (Table 2) made by ten informants showed that Bersema abyssinaca ranked first and hence is the most effective medicinal plant to cure snake biting. Myrsine melanophloeos, Nicotiana tabacum, Justicia schimperiana and Allium sativum. Are the $2^{\text {nd }}, 3^{\text {rd }}, 4^{\text {th }}$ and $5^{\text {th }}$ respectively.

Table 2. Preference ranking of eleven Selected Medicinal Plants based on the Degree of their Curative Power of snake bit as Perceived by Informants.

\begin{tabular}{|c|c|c|c|c|c|c|c|c|c|c|c|c|}
\hline \multirow[b]{2}{*}{ Name of plants species } & \multicolumn{12}{|c|}{ Respondents(R1-R10) } \\
\hline & $\mathbf{R}_{\mathbf{1}}$ & $\mathbf{R}_{2}$ & $\mathbf{R}_{3}$ & $\mathbf{R}_{4}$ & $\mathbf{R}_{\mathbf{5}}$ & $\mathbf{R}_{\mathbf{6}}$ & $\mathbf{R}_{7}$ & $\mathbf{R}_{8}$ & $\mathbf{R}_{\mathbf{9}}$ & $\mathbf{R}_{10}$ & Total & Rank \\
\hline Allium sativum $\mathrm{L}$. & 4 & 3 & 5 & 3 & 4 & 5 & 1 & 5 & 5 & 3 & 38 & $5^{\text {th }}$ \\
\hline Carduus englariaum Sch. Bip. Ex A. Rich. & 2 & 3 & 1 & 1 & 2 & 3 & 4 & 3 & 3 & 5 & 27 & $9^{\text {th }}$ \\
\hline Carissa spinarum L. & 2 & 5 & 5 & 4 & 5 & 5 & 2 & 5 & 3 & 1 & 37 & $6^{\text {th }}$ \\
\hline Justicia schimperiana (Hochst. ex Nees) T. Anders. & 4 & 5 & 5 & 2 & 5 & 4 & 5 & 4 & 2 & 3 & 39 & $4^{\text {th }}$ \\
\hline Lagenaria siceraria (Mol.) Standl. & 4 & 4 & 0 & 1 & 4 & 3 & 2 & 2 & 1 & 3 & 24 & $11^{\text {th }}$ \\
\hline Nicotiana tabacum L. & 3 & 5 & 2 & 4 & 4 & 5 & 5 & 3 & 5 & 5 & 41 & $3^{\text {rd }}$ \\
\hline Paveonia urenscav & 5 & 2 & 5 & 3 & 2 & 4 & 5 & 4 & 1 & 5 & 36 & $6^{\text {th }}$ \\
\hline Stereospermum kunthianum & 4 & 2 & 2 & 4 & 5 & 2 & 2 & 5 & 5 & 4 & 30 & $9^{\text {th }}$ \\
\hline Bersema abyssinaca & 5 & 5 & 5 & 4 & 5 & 5 & 4 & 4 & 5 & 5 & 47 & $1^{\mathrm{st}}$ \\
\hline Dicrocephale latifolia & 5 & 4 & 2 & 2 & 3 & 2 & 3 & 3 & 3 & 4 & 31 & $8^{\text {th }}$ \\
\hline Myrsine melanophloeos & 5 & 4 & 4 & 5 & 5 & 5 & 4 & 5 & 5 & 4 & 46 & $2^{\text {nd }}$ \\
\hline
\end{tabular}

\subsubsection{Direct Matrix Ranking}

Direct matrix ranking was performed to assess the relative importance each of the plant. The result of the direct matrix ranking showed that Cordia africana stood first in being the most multipurpose medicinal plant followed by Gardenia ternifolia, Eucalyptus globulus, Myrsine melanophloeos Croton macrostachyus Del. Acacia abyssinica, Ximenia caffra. sond, Bersema abyssinaca and Jatropha curcas was the least (Table 3).

Table 3. Direct matrix ranking for seven specie and main use in study area.

\begin{tabular}{|c|c|c|c|c|c|c|c|c|c|}
\hline \multirow{2}{*}{ NamePlant species } & \multicolumn{9}{|c|}{ Use categories } \\
\hline & Charcoal & Construction & Medicine & Food & Firewood & Fencing & Furniture & Total & Rank \\
\hline Jatropha curcas & 0 & 0 & 4 & 0 & 3 & 5 & 1 & 13 & $9^{\text {th }}$ \\
\hline Ximenia caffra. sond & 0 & 2 & 5 & 5 & 5 & 3 & 2 & 22 & $7^{\text {th }}$ \\
\hline Cordia africana Lam. & 5 & 5 & 5 & 4 & 5 & 3 & 5 & 32 & $1^{\text {st }}$ \\
\hline Croton macrostachyus Del. & 5 & 5 & 5 & 0 & 4 & 4 & 2 & 24 & $5^{\text {th }}$ \\
\hline Acacia abyssinica & 5 & 5 & 3 & 0 & 4 & 3 & 3 & 23 & $6^{\text {th }}$ \\
\hline Eucalyptus globulus & 5 & 5 & 3 & 0 & 5 & 5 & 5 & 28 & $3^{\text {rd }}$ \\
\hline
\end{tabular}




\begin{tabular}{|c|c|c|c|c|c|c|c|c|c|}
\hline \multirow{2}{*}{ NamePlant species } & \multicolumn{9}{|c|}{ Use categories } \\
\hline & Charcoal & Construction & Medicine & Food & Firewood & Fencing & Furniture & Total & Rank \\
\hline Myrsine melanophloeos & 5 & 5 & 5 & 0 & 5 & 2 & 3 & 25 & $4^{\text {th }}$ \\
\hline Bersema abyssinaca & 1 & 2 & 5 & 0 & 3 & 3 & 1 & 15 & $8^{\text {th }}$ \\
\hline Gardenia ternifolia & 2 & 3 & 5 & 3 & 4 & 3 & 5 & 30 & $2^{\text {nd }}$ \\
\hline Total & 33 & 30 & 40 & 12 & 47 & 31 & 23 & & \\
\hline Rank & $3^{\text {rd }}$ & $5^{\text {th }}$ & $2^{\text {nd }}$ & $7^{\text {th }}$ & $1^{\mathrm{st}}$ & $4^{\text {th }}$ & $6^{\text {th }}$ & & \\
\hline
\end{tabular}

\subsubsection{Paired Comparison}

A paired comparison made to determine the most preferred medicinal plants among the 9 species that were used to treat eye vile in the study area, the responses of ten key informants, showed that Ranked Withania somnifera first followed by
Gardenia ternifoli is the second (Table 4). Therefore, this result indicated that Withania somnifera is the most preferred while. Clausena anisata is the least favored over the other plant species cited in treating eye vile.

Table 4. Paired comparisons of five medicinal plant species used to treat fibril illness.

\begin{tabular}{|c|c|c|c|c|c|c|c|c|c|c|c|c|}
\hline \multirow{2}{*}{ Name of plants species } & \multicolumn{12}{|c|}{ Respondents(R1-R10) } \\
\hline & $\mathbf{R}_{1}$ & $\mathbf{R}_{2}$ & $\mathbf{R}_{\mathbf{3}}$ & $\mathbf{R}_{4}$ & $\mathbf{R}_{\mathbf{5}}$ & $\mathbf{R}_{6}$ & $\mathbf{R}_{7}$ & $\mathbf{R}_{8}$ & $\mathbf{R}_{\mathbf{9}}$ & $\mathbf{R}_{10}$ & Total & Rank \\
\hline Gardenia ternifolia & 1 & 4 & 3 & 0 & 1 & 1 & 2 & 4 & 5 & 4 & 35 & $2^{\text {nd }}$ \\
\hline Acacia abyssinica & 4 & 1 & 2 & 2 & 4 & 5 & 5 & 4 & 2 & 1 & 30 & $4^{\text {th }}$ \\
\hline Allium sativum L. & 2 & 2 & 1 & 4 & 3 & 2 & 4 & 3 & 2 & 5 & 28 & $5^{\text {th }}$ \\
\hline Croton macrostachyus Del & 5 & 5 & 1 & 4 & 2 & 2 & 1 & 0 & 1 & 4 & 25 & $8^{\text {th }}$ \\
\hline Vernonia amygdalina Del. & 1 & 0 & 2 & 4 & 3 & 1 & 4 & 1 & 5 & 1 & 27 & $6^{\text {th }}$ \\
\hline Clausena anisata & 4 & 4 & 1 & 0 & 4 & 1 & 4 & 3 & 1 & 0 & 22 & $9^{\text {th }}$ \\
\hline Capparis tomentosa & 1 & 2 & 4 & 2 & 4 & 2 & 4 & 4 & 3 & 5 & 31 & $3^{\text {rd }}$ \\
\hline Withania somnifera & 4 & 2 & 4 & 4 & 5 & 1 & 5 & 4 & 4 & 5 & 38 & $1^{\mathrm{st}}$ \\
\hline
\end{tabular}

\section{Threatened and Factor Threatening Medicinal Plants in Dibati Woreda}

\subsection{Threatened Medicinal Plant in the Study Area}

The ranking of 9 medicinal plants based on the degree of threats was conducted using 10 key informants. (Table 5) The results indicated that is Asparagus africanus and Myrsine melanophloeos the most threatened followed by Withania somnifera (L.) and Bersema abyssinaca and the least threatened one is Glinus lotoides $L$.

Table 5. Ranking of threatened plants.

\begin{tabular}{|c|c|c|c|c|c|c|c|c|c|c|c|c|}
\hline \multirow{2}{*}{ Name of plants species } & \multicolumn{12}{|c|}{ Respondents(R1-R10) } \\
\hline & $\mathbf{R}_{1}$ & $\mathbf{R}_{2}$ & $\mathbf{R}_{3}$ & $\mathbf{R}_{4}$ & $\mathbf{R}_{5}$ & $\mathbf{R}_{6}$ & $\mathbf{R}_{7}$ & $\mathbf{R}_{8}$ & $\mathbf{R}_{9}$ & $\mathbf{R}_{10}$ & Total & Rank \\
\hline Myrsine melanophloeos & 1 & 4 & 3 & 0 & 1 & 1 & 2 & 4 & 5 & 4 & 35 & $2^{\text {nd }}$ \\
\hline Bersema abyssinaca & 4 & 1 & 2 & 2 & 4 & 5 & 5 & 4 & 2 & 1 & 30 & $4^{\text {th }}$ \\
\hline Paveonia urenscav & 2 & 2 & 1 & 4 & 3 & 2 & 4 & 3 & 2 & 5 & 28 & $5^{\text {th }}$ \\
\hline Oncoba spinosa Forssk. & 5 & 5 & 1 & 4 & 2 & 2 & 1 & 0 & 1 & 4 & 25 & $8^{\text {th }}$ \\
\hline Momoridica foetida.schum & 1 & 0 & 2 & 4 & 3 & 1 & 4 & 1 & 5 & 1 & 27 & $6^{\text {th }}$ \\
\hline Kalancheo petitiana A.Rich, & 4 & 1 & 0 & 4 & 1 & 2 & 1 & 4 & 5 & 4 & 26 & $7^{\text {th }}$ \\
\hline Glinus lotoides L. & 4 & 4 & 1 & 0 & 4 & 1 & 4 & 3 & 1 & 0 & 22 & $9^{\text {th }}$ \\
\hline Withania somnifera (L.) & 1 & 2 & 4 & 2 & 4 & 2 & 4 & 4 & 3 & 5 & 31 & $3^{\text {rd }}$ \\
\hline Asparagus africanus & 4 & 2 & 4 & 4 & 5 & 1 & 5 & 4 & 4 & 5 & 38 & $1^{\mathrm{st}}$ \\
\hline
\end{tabular}

\subsection{Factors Threatening Medicinal Plants in the Study Area}

The cause of threats to medicinal plants can be generally grouped into natural and human induced factors. However, as reported in this study most of the causes for the threats to medicinal plants and the associated indigenous knowledge are the anthropogenic factors such as deforestation due to over exploitation of plants for different uses including charcoal making, population pressure, fire wood collection, house hold construction, overgrazing, cutting and burning of plants to create new agricultural expansion lands and urbanization. Informants ranked agricultural expansion, fire wood and population pressure as the most serious threat to the medicinal plants followed by medicinal purpose and charcoal collection is lower levels of threats by the other factors (Table 6). Similar study b $[18,12,3,28,36]$. This showed that, there are different threats in medicinal plants such as agricultural expansion fire wood collection and 
others. Furthermore, the negative impact of deforestation on medicinal plants was also reported [15].

In this study, the information gathered from the key informants was indicated that the treats of medicinal plants increase from time to time in study area. The agricultural expansion and deforestation was the major medicinal plant treats. The finding was in line with other findings [15]. This might be due to continuous agricultural expansions, deforestation and draught in addition to lack attention towards the medicinal plants. The plants are disappeared because of rapid socioeconomic, environmental and technological changes and as a result of the loss of cultural heritage under the guise of civilization [11].

Table 6. Ranking of threats to medicinal plants.

\begin{tabular}{|c|c|c|c|c|c|c|c|c|c|c|c|c|}
\hline \multirow{2}{*}{ Name of plants species } & \multicolumn{12}{|c|}{ Respondents(R1-R10) } \\
\hline & $\mathbf{R}_{1}$ & $\mathbf{R}_{\mathbf{2}}$ & $\mathbf{R}_{\mathbf{3}}$ & $\mathbf{R}_{4}$ & $\mathbf{R}_{\mathbf{5}}$ & $\mathbf{R}_{6}$ & $\mathbf{R}_{7}$ & $\mathbf{R}_{8}$ & $\mathbf{R}_{\mathbf{9}}$ & $\mathbf{R}_{10}$ & Total & Rank \\
\hline Fire wood & 4 & 5 & 5 & 4 & 3 & 4 & 3 & 5 & 2 & 5 & 40 & $2^{\text {nd }}$ \\
\hline Medicinal purpose & 2 & 1 & 2 & 1 & 2 & 2 & 1 & 2 & 2 & 1 & 16 & $8^{\text {th }}$. \\
\hline Charcoal Making & 4 & 2 & 3 & 2 & 3 & 1 & 3 & 4 & 1 & 3 & 23 & $7^{\text {th }}$ \\
\hline Household tool construction & 4 & 5 & 5 & 3 & 1 & 2 & 4 & 4 & 2 & 3 & 33 & $6^{\text {th }}$ \\
\hline Over grazing & 3 & 4 & 4 & 2 & 5 & 5 & 4 & 3 & 2 & 3 & 35 & $4^{\text {th }}$ \\
\hline Urbanization & 3 & 2 & 4 & 5 & 4 & 3 & 2 & 2 & 5 & 4 & 34 & $5^{\text {th }}$ \\
\hline population pressure & 5 & 2 & 3 & 4 & 5 & 5 & 3 & 3 & 4 & 5 & 39 & $3^{\mathrm{rd}}$ \\
\hline
\end{tabular}

\subsection{Management and Conservation of Medicinal Plants}

At this moment natural habitats of medicinal plants in the study area are highly affected by factors mentioned above. The local people in the study area have brought only about 48 and 17 species of the total collected medicinal plants under wild and home garden. As a result many medicinal plants are under serious threats. So the local people should be conserve medicinal plant in-suit and ex- suit management style.

Those manes that forty-eight medicinal plants that are collected in the wild by conserve in-suit conservation method and the reaming seventeen medicinal plants that conserve by ex-suit conservation method. According to the informant information generally, there are some conservation measures that have been under taken around the world aimed at protecting threatened medicinal plant species from further destruction by create awareness for the user local people for the use and management of medicinal plant in study area.

Some authors clarify that home gardens can be refuge for wild species that are threatened in the wild by deforestation and environmental changes Concerning this [37] Reported that home gardens are being used as informal experimentation plots for new varieties and exotic species.

Medicinal plants are also left as remnants of trees, shrubs and herbs in and around agricultural fields due to their uses as forage, fuel wood, timber, and construction, spiritual and ritual needs. Protecting such multi-purpose plant species by agro-pastoralists in their localities is evidence for the existence of traditional conservation practices in the area. But this has to be strengthened to safeguard these natural resources. Of the species purposely maintained in home gardens in the country, about $6 \%$ are primarily cultivated for their medicinal values [37].

Informants also reported that the healers know time and processes of gathering, and storing medicinal plants. It is once a year that some medicinal plants are collected and preserved. Lepidium sativum, Cucuribita pepo, Jatropha curcas and Ocimim basilicum seed, leaf, fruit or root are harvested, dried and preserved in roof corners or outside house, and dried parts are powdered and stored in different containers like pots, bottles or tied with clothes and used when needed.

The study indicated that many of the informants who have knowledge on traditional medicine usage give priority to the immediate use of the medicinal plants than to its sustainable future uses, as a result their harvesting style is destructive. However, some plants has protected for their spiritual and cultural purposes. Thus, these places are good sites for the protection of the medicinal plants since cutting and harvesting are not allowed in such particular areas. This was indicated that a good practice for the conservation of medicinal plants through cultivation. [28].

\subsection{Informant Consensus Factor (ICF)}

All cited human and livestock diseases were categorized into 7 categories: namely, Sense organs related diseases, Animal and insect biting related disease, digestive system related disease, Reproductive system related diseases, Cultural related disease, Respiratory disease related diseases, intestinal and parasitic infection related diseases, and derma related disease, These diseases are categorized based on nature of disease, conditions that cause, place of attack, symptoms and sign of disease (Table 7). Disease categories with relatively higher ICF values were: intestinal and parasitic infection related diseases (0.89), derma related diseases (0.87) Sense organs related diseases $(0.83)$, and Cultural related diseases (0.73). This may indicate the common occurrence of these diseases so that more number of people exchanging information and agree on plant species that can be used to treat these diseases than the rest. The medicinal plants that are presumed to be effective in treating a certain disease have higher ICF values. On the other hand, the rest of disease categories had ICF value of lower suggesting that these diseases are either rare in the study area 
or are treated only by the healers with little information

passed to other general public [22].

Table 7. Informant consensus factor (ICF).

\begin{tabular}{|c|c|c|c|c|}
\hline Categories & Ailments/diseases & $\begin{array}{l}\text { Number of Species } \\
\text { used (nt) }\end{array}$ & $\begin{array}{l}\text { Use citation } \\
\text { (nur) }\end{array}$ & $\begin{array}{l}\text { ICF } \\
\text { Value }\end{array}$ \\
\hline Sense organs & Eye problem, ear problem, trachoma, & 5 & 25 & 0.83 \\
\hline Animal and insect biting & snake bite, rabies, malaria, spider poison, scorpion poisons & 23 & 69 & 0.64 \\
\hline digestive system & Stomach ache,, bloat, diarrhea, toothache, gastritis abdominal pain & 25 & 81 & 0.70 \\
\hline Reproductive system & gonorrhea, sexual weakens diseases, retained placenta, infertility RH factor & 11 & 33 & 0.68 \\
\hline Respiratory diseases & Nasal bleeding,, tonsillitis, cough and asthma, common cold, leech & 16 & 28 & 0.44 \\
\hline intestinal and parasitic infection & Tap worm, ascarisis & 6 & 49 & 0.89 \\
\hline dermal & $\begin{array}{l}\text { Dandruff, wound, skin rash, body swell, bone broken } \\
\text { Leprosy goiter, ring worm mouth rash Athletes foot }\end{array}$ & 8 & 58 & 0.87 \\
\hline Cultural releted & Eye vile, feberal ilnes, headache, preventing snake & 18 & 64 & 0.73 \\
\hline
\end{tabular}

\subsection{Fidelity Level Index (FLI)}

Fidelity level (FL) quantifies the importance of a species for a given purpose. Hence, fidelity level values were calculated for commonly used individual medicinal plants against the following ailments: Justicia schimperiana(against snake biting and Rabbis) Nicotiana tabacum L.( against leech) Asparagus africanaus (against retained of placenta) Croton macrostachyus (against eye vile), Stereospermum kunthianum (Tonsil, scorpion biting), Momoridica foetida. schum (against Bleeding during delivery) Myrsine melanophloeos (against blackleg) Euphorbia abyssinica (against Hemorrhoid, gonorrhea) Paveonia urenscav (against Rheumatic, tooth ache)and Protulaca sp.( against Gastritis). The fact that these medicinal plants had the highest FL values which could be an indication of their good healing potential (Table 8).

Table 8. The relative healing potential of individual medicinal plants used against human or livestock ailments.

\begin{tabular}{|c|c|c|c|c|c|c|}
\hline No & Medicinal plants species & Aliments treated & IP & IU & FLI (\%) & Rank \\
\hline 1 & Croton macrostachyus & Evile eye & 52 & 58 & 89.6 & $4^{\text {th }}$ \\
\hline 2 & Justicia schimperiana (Hochst. ex Nees) T. Anders. & Snake biting, rabbis & 47 & 47 & 100 & $1^{\text {st }}$ \\
\hline 3 & Nicotiana tabacum $L$. & Leech, & 45 & 48 & 93.75 & $2^{\text {nd }}$ \\
\hline 4 & Asparagus africanus (kunth) Baker & Retained placenta & 38 & 41 & 92.6 & $3^{\text {rd }}$ \\
\hline 5 & Myrsine melanophloeos & Black leg & 37 & 45 & 82.22 & $7^{\text {th }}$ \\
\hline 6 & Stereospermum kunthianum Cham. & Tonsil, scorpion biting & 31 & 35 & 88.57 & $5^{\text {th }}$ \\
\hline 7 & Euphorbia abyssinica J.F Gmel & Hemorrhoid, gonorrhea & 29 & 37 & 78.38 & $8^{\text {th }}$ \\
\hline 9 & Protulaca sp. & Gastritis & 21 & 29 & 72.4 & $10^{\text {th }}$ \\
\hline 10 & Paveonia urenscav & Rheumatic, tooth ache & 19 & 25 & 76.0 & $9^{\text {th }}$ \\
\hline
\end{tabular}

\subsection{Medicinal Use Value}

While some plant species are known to treat a single ailment, some others may be used for multiple of health problems. Medicinal use value is a quantitative method that demonstrates the relative importance of species known locally [19].

Some species that were cited for more than one ailment were selected and their use value was calculated. Results of use value computation for these species showed that Croton macrostachyus and had the Carissa spinarum highest use value (Table 9). The informant consensus values also indicated that the people share the knowledge of the most important medicinal plant species to treat the most frequently encountered diseases in the community. Moreover, most medicinal plant species have least use values in the study area, which could not mean that they are less effective to treat ailments. This is because the few effective medicinal plant species are reported by one or two healers. In this case, the knowledge is very secret. This suggests that these species are used to treat many ailments. For example, Croton macrostachyus was reported to treat ailments such amoeba, evil eye, febrile illness, wound, prevent snake, skin infection and malaria. On the other hand was Carissa spinarum L. reported to treat snake biting, ascarises, malaria, gonorrhea, Amoeba, febrile illness and diarrhea. Justicia schimperiana was reported to treat aliments such as snake biting, anti-toxic stabbing malaria, rabbis and typhoid's. Stereospermum kunthianum was reported to treat aliments such as scropion biting, retained plasta, gasterite, tosile, snake biting and stomachache.

Table 9. Use Value of Certain Medicinal Plants in Study Area.

\begin{tabular}{|c|c|c|c|}
\hline Plant species & Use citation( $(U)$ & Number of informants(n) & Use value (Uv) \\
\hline Croton macrostachyus & 7 & 23 & 0.35 \\
\hline Carissa spinarum L. & 7 & 19 & 0.37 \\
\hline Stereospermum kunthianum Cham. & 6 & 12 & 0.50 \\
\hline
\end{tabular}




\begin{tabular}{llll}
\hline Plant species & Use citation(U) & Number of informants(n) & Use value (Uv) \\
\hline Vernonia amygdalina Del. & 5 & 12 & 0.42 \\
Combretum collinum & 5 & 13 & 0.38 \\
Paveonia urenscav & 5 & 15 & 0.33 \\
Cordia africana Lam. & 5 & 23 & 0.22 \\
Solanu nigrum & 4 & 11 & 0.36 \\
Kalancheo petitiana A.Rich & 4 & 9 & 0.44 \\
Gardenia lutea Fresen. & 4 & 12 & 0.33 \\
Allium sativum L. & 3 & 7 & 0.43 \\
Clutia abyssinica Jaub. and Spach & 3 & 5 & 0.60 \\
Coffea arabica L. & 3 & 25 & 0.12 \\
Ximenia caffra.sond & 3 & 8 & 0.38 \\
Nicotiana tabacum L. & 3 & 7 & 0.43 \\
Ruta chalepensis L. & 3 & 19 & 0.16 \\
Eucalyptus globulus.Labil. & 3 & 20 & 0.15 \\
Zingiber officinale Roscoe, & 3 & 15 & 0.20 \\
Clematis hirsuta perr and Guill & 3 & 12 & 0.25 \\
Euphorbia abyssinica J.F Gmel & 3 & 4 & 0.75 \\
Linum usitatissimum L. & 3 & 11 & 0.27 \\
Oncoba spinosa Forssk. & 3 & 9 & 0.33 \\
\hline
\end{tabular}

\section{Conclusion}

Dibati woreda is one the most rich medicinal plant species and the associated indigenous knowledge. In this study area 39 family, 62 genera and 65 medicinal plant species were recorded. Of these, $48(47.6 \%)$ and $17(21.9 \%)$ of the species were reported as seeing used to treat human ailments and livestock respectively, while $30.5 \%$ of them were reported to treat both livestock and human ailments. The majorities of these medicinal plant species were obtained and collected 48 from wild, 17 from home garden. Analysis of growth forms of these medicinal plants that herbs constitute the largest category $24(36.9 \%)$ followed by tree $18(27.69 \%)$ shrub $16(24.61)$ and climber $7(10.76 \%)$ plant species. Herbal remedies are prepared from fresh materials $45(62.23 \%)$ and dried plant materials $8(12.30 \%)$ and in both condation $18(18.46 \%)$. In the study area, 72 ailments were reported (57 for human and 15 for livestock) which are being treated by traditional medicinal plants of the area.

Leaves were the most frequently used plant parts followed by roots for preparation of human and livestock remedies.
Most of the medicinal plants are administered orally (54.4\%) and followed dermal (7.69). The most widely used method of preparation was crashed (23.07\%), Pounding (20\%), squeezed $(15.4 \%)$, chewing $(10.7 \%)$ crushed pounded, cocking, smoking eating of the different medicinal plant parts.

The shinasha people of Dibati Woreda are rich with indigenous knowledge in using, conserving and managing plant resources in general and medicinal plants in particular. They have a wide knowledge in using plants for various purposes such as for medicine, food, household utensils, fodder, fuel, construction, etc. This knowledge is transferred from elders to youngsters entirely through oral traditions and personal experiences. But this way of knowledge transmission will lead to distortion of the original knowledge or total disappearance of the practice. The major threats to medicinal plants and the associated knowledge in the study area are mainly agricultural expansion, firewood collection, population pressure, over gaze ring, urbanization, household tool construction, charcoal production and medicinal purpose. Therefore, use and management system awareness rising should be made among the healers so as to avoid erosion of the indigenous knowledge and to ensure its sustainable use.

\section{Appendix}

Table 10. Lists of medicinal plants used to treat human in the Dibati woreda by shinasha people.

\begin{tabular}{|c|c|c|c|c|c|}
\hline Scientific Name & Family & Local Name & $\begin{array}{l}\text { Parts } \\
\text { used }\end{array}$ & Disease Treated & Mode of Preparation and dose \\
\hline \multirow{3}{*}{$\begin{array}{l}\text { Acacia abyssinica } \\
\text { hochst.ex. Benth. }\end{array}$} & \multirow{3}{*}{ Fabaceae } & \multirow{3}{*}{ Sipa/ Grara } & Leaf & Nose bleeding & Squeeze flashy leaf and drop to nostrils for 3-5 days \\
\hline & & & Root & Eye vile & Root is crushed and fumigated during the night time for 3 day. \\
\hline & & & & Abdominal pain & $\begin{array}{l}\text { Crash the bulb and mixed with honey take a tea of spoon in each } \\
\text { morning for } 2 \text { days }\end{array}$ \\
\hline Allium sativum L. & Alliaceae & Nas' shink'urt'a & Bulb & Common cold & $\begin{array}{l}\text { Crashing the bulb and swallow it. Additional insert the bulb in } \\
\text { nostrils }\end{array}$ \\
\hline \multirow{2}{*}{$\begin{array}{l}\text { Carduus schimperi } \\
\text { Sch. Bip. ex A. Rich }\end{array}$} & \multirow[b]{2}{*}{ Asteraceae } & \multirow[b]{2}{*}{ Gali koshoshela } & Leaf & Wound & The leaf is crashed then drink one glass for 3-5 days \\
\hline & & & Root & Snake bit & $\begin{array}{l}\text { Root is crushed, pounded then mix with water and drink one } \\
\text { cup during the biting time }\end{array}$ \\
\hline \multirow[t]{2}{*}{ Carissa spinarum L. } & \multirow[t]{2}{*}{ Apocynaceae } & \multirow[t]{2}{*}{ Awawa/Agam } & Root & Snake biting & $\begin{array}{l}\text { The root is pounded, squeezed and drink one cup during biting } \\
\text { time }\end{array}$ \\
\hline & & & Root & Ascarises & The root is crushed then drink one cup for 3 day. \\
\hline
\end{tabular}




\begin{tabular}{|c|c|c|c|c|c|}
\hline Scientific Name & Family & Local Name & $\begin{array}{l}\text { Parts } \\
\text { used }\end{array}$ & Disease Treated & Mode of Preparation and dose \\
\hline \multirow{8}{*}{$\begin{array}{l}\text { Clutia abyssinica Jaub. } \\
\text { and Spach }\end{array}$} & \multirow{8}{*}{ Euphorbiaceae } & \multirow{8}{*}{ Batska/feyele feg } & Root & Malaria & $\begin{array}{l}\text { The root is pounded squeezed and drink one cup of coffee for } 3 \\
\text { dayes before eating any food. }\end{array}$ \\
\hline & & & Root & Gonorrhea & $\begin{array}{l}\text { Root is crushed and mixed with water then drink one cup for } 5 \\
\text { day. }\end{array}$ \\
\hline & & & Root & Fibril illness & $\begin{array}{l}\text { Crashed the root then burned for continuous every night time } \\
\text { for } 3 \text { day. }\end{array}$ \\
\hline & & & Root & Amoeba & Crashed the root and smashed then drink one cup for $3-5$ days \\
\hline & & & Leaf & Diarrhea & Crashed the leaf and smashed then drink one cup for 3-5 days \\
\hline & & & Leaf & Prevent snake & The leaf is pounded then burn in the house. \\
\hline & & & Leaf & Ear disease & The leaf is pounded, squeezed and then its drop through ear. \\
\hline & & & Leaf & Dandruff & $\begin{array}{l}\text { The leaf is pounded, squeezed and creamed affected part until } \\
\text { recovery for 3-5 day. }\end{array}$ \\
\hline \multirow{3}{*}{ Coffea arabica L. } & \multirow{3}{*}{ Rubiaceae } & \multirow{3}{*}{ Buna } & Leaf & Asthma & The leaf is crashed then drink one cup for 3 days before eating food. \\
\hline & & & & Fire burn & $\begin{array}{l}\text { The seed is roasted, crusned, powdered and appiled on wounded } \\
\text { The seed of Coffea arabica is roasted, crushed, powdered, boiled }\end{array}$ \\
\hline & & & Seed & Diarrhea & $\begin{array}{l}\text { and the filtrate one cup of tea, mixed with few drop of oil then } \\
\text { drunk. }\end{array}$ \\
\hline \multirow{5}{*}{ Cordia africana Lam. } & \multirow{5}{*}{ Boraginaceae } & \multirow{5}{*}{ Baaja/Wanze } & $\begin{array}{l}\text { Root } \\
\text { break }\end{array}$ & $\begin{array}{l}\text { Diarrhea with } \\
\text { blood }\end{array}$ & The root and the break crashed then drink two galas for 2 day. \\
\hline & & & Break & Stomach Pain & $\begin{array}{l}\text { Crashing the break then pounding and extract the liquid drink } \\
\text { one glas for 3-5 day. }\end{array}$ \\
\hline & & & Break & Liver diseases & $\begin{array}{l}\text { The break is crushed, pounded then mix with water and } \\
\text { squeezed then drink one cup for } 3 \text { day. }\end{array}$ \\
\hline & & & Root & Tonsils & The root chewing before eating food for 3 day. \\
\hline & & & Break & $\begin{array}{l}\text { Bleeding during } \\
\text { delivering }\end{array}$ & $\begin{array}{l}\text { The break crashed pounding then extract the liquid drink it one } \\
\text { cup for once }\end{array}$ \\
\hline \multirow{8}{*}{$\begin{array}{l}\text { Croton macrostachyus } \\
\text { Del. }\end{array}$} & \multirow{8}{*}{ Euphorbiaceae } & \multirow{8}{*}{ Baroha/Bisana } & Leaf & Skin diseases & $\begin{array}{l}\text { The leave of shoot is squeezed and the content is dropped on } \\
\text { infected sited }\end{array}$ \\
\hline & & & & Prevent snake & The epiphyte is burn in the area of snake \\
\hline & & & Epiphyte & Eye vile & $\begin{array}{l}\text { The epiphyte is fumigate in the people is attack with it during } \\
\text { starting time. }\end{array}$ \\
\hline & & & & Fibril illness & The collect epiphyte then fumigate every night for 3 day. \\
\hline & & & Leaf & Malaria & The leaf cocking then one cup drinks the liquid for 3 day. \\
\hline & & & Break & Amoeba & $\begin{array}{l}\text { Crushed the break and mix with water and squeezed then drink } \\
\text { one cup for } 2 \text { day. }\end{array}$ \\
\hline & & & Break & $\begin{array}{l}\text { Eye disease } \\
\text { (trachoma) }\end{array}$ & $\begin{array}{l}\text { The beak is crashed; pounding then washed the face morning } \\
\text { for } 3 \text { day. }\end{array}$ \\
\hline & & & Snap & Wound & The fresh latex is applied on the Infected part \\
\hline \multirow{4}{*}{ Solanu nigrum $\mathrm{L}$. } & \multirow{4}{*}{ Solanaceace } & \multirow{4}{*}{ Ump'ap'a/ embay } & $\begin{array}{l}\text { Fruit of } \\
\text { snap }\end{array}$ & Hemorrhoids. & The fruit snap added on Hemorrhoids area. \\
\hline & & & Root & Stomach ache & $\begin{array}{l}\text { The root of is chewing and swallowing during the feeling of } \\
\text { ache for } 3 \text { day }\end{array}$ \\
\hline & & & Root & Scorpion biting & The root is chewing and swallowing during biting time. \\
\hline & & & Leaf & Cough & $\begin{array}{l}\text { The leaf is pounded, powdered and mixed with honey and then } \\
\text { drunk for } 3 \text { days. }\end{array}$ \\
\hline \multirow[t]{2}{*}{ Datura stramonium L } & \multirow[t]{2}{*}{ Solanaceae } & \multirow[t]{2}{*}{ Eelefila/Astenager } & Leaf & Dandruff & $\begin{array}{l}\text { The fresh leaf is squeezed and creamed affected part until } \\
\text { recovery for } 3 \text { day. }\end{array}$ \\
\hline & & & & Wound & The leave crashed and applied to affected area for 5 day. \\
\hline \multirow{3}{*}{$\begin{array}{l}\text { Eucalyptus globulus } \\
\text { Labill, }\end{array}$} & \multirow{3}{*}{ Myrtaceae } & \multirow{3}{*}{ Nas' Baahirzaafiya } & Root & Common cold & $\begin{array}{l}\text { Crashed the root and mixed with sugar then extract drink one } \\
\text { gales for } 3 \text { day. }\end{array}$ \\
\hline & & & Leaf & Fibril illness & $\begin{array}{l}\text { The leaf is crashed then burn on fire in fumigate every night for } \\
\text { the } 3 \text { day. }\end{array}$ \\
\hline & & & Root & Dry Cough & $\begin{array}{l}\text { The root crushed and pounded then mixed with water and } \\
\text { squeezed then drink one glass for } 3 \text { day. }\end{array}$ \\
\hline \multirow{7}{*}{$\begin{array}{l}\text { Justicia schimperiana } \\
\text { (Hochst. ex Nees) } \\
\text { T. Anders. }\end{array}$} & \multirow{7}{*}{ Acanthaceae } & \multirow{7}{*}{ Simiza } & Jeot & Snake bit & $\begin{array}{l}\text { The crushed the leaf then pounding drinks one glass during } \\
\text { biting time. }\end{array}$ \\
\hline & & & Leat & Antitoxic & $\begin{array}{l}\text { The crushed the leaf then pounding drinks one glass during } \\
\text { taking any chemical time. }\end{array}$ \\
\hline & & & Root & $\begin{array}{l}\text { Wugat/ Stabbing } \\
\text { pain }\end{array}$ & $\begin{array}{l}\text { The root is crashed and mixed with honey and drink one gales } \\
\text { for 3-5 day }\end{array}$ \\
\hline & & & Leaf & Malaria & $\begin{array}{l}\text { The leaf is crashed and mixed with water then extract the drink } \\
\text { one gales for } 3 \text { day. }\end{array}$ \\
\hline & & & Root & Rabbis & The root crashed pounding then drink one cup for 3 dyes \\
\hline & & & Root & Snake bit & $\begin{array}{l}\text { Crashed the root and pounding the drink one cup during biting } \\
\text { time. }\end{array}$ \\
\hline & & & Root & Typhoid & Root is crushed then mixes with water and squeezed one cup \\
\hline
\end{tabular}




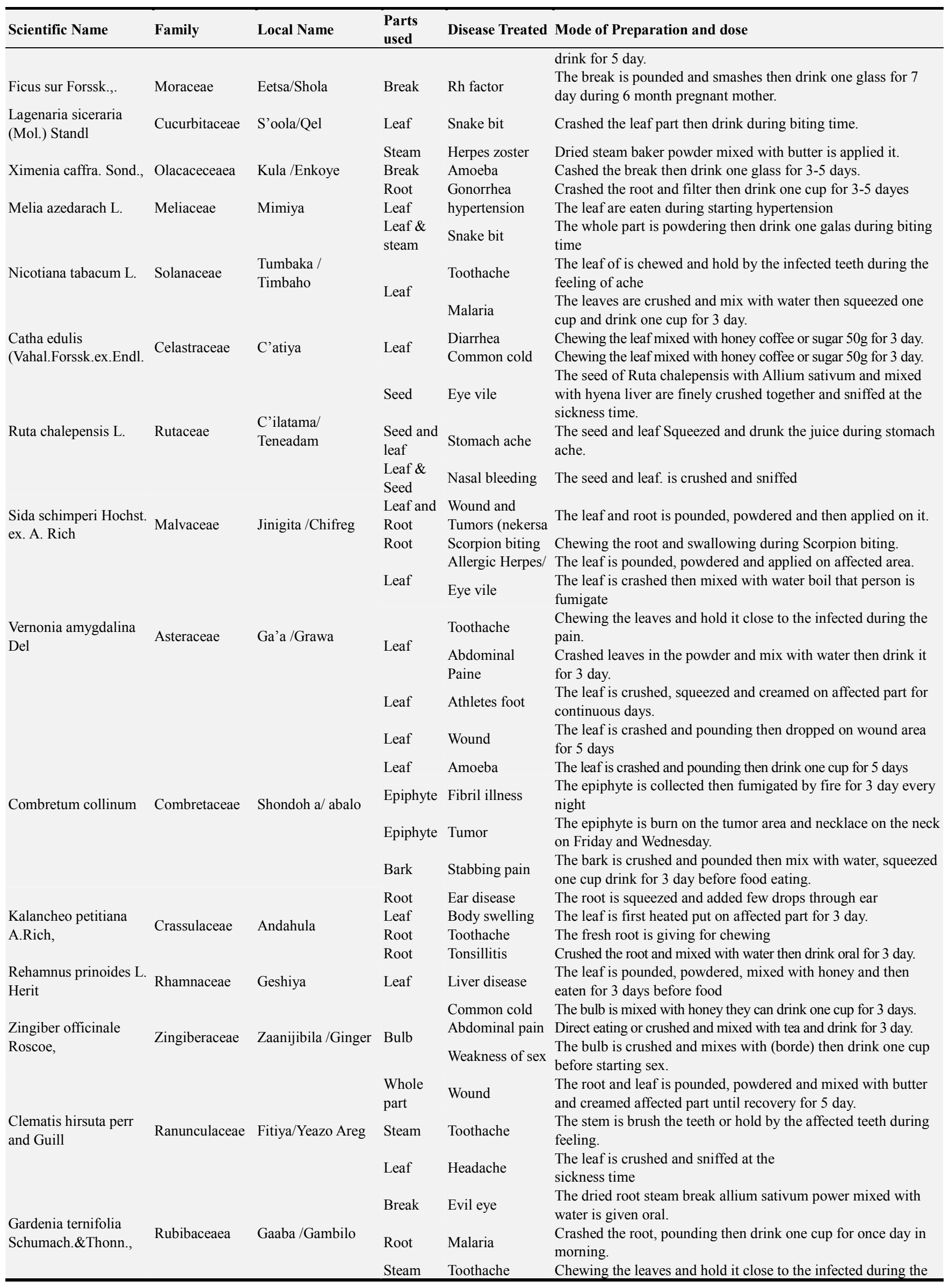




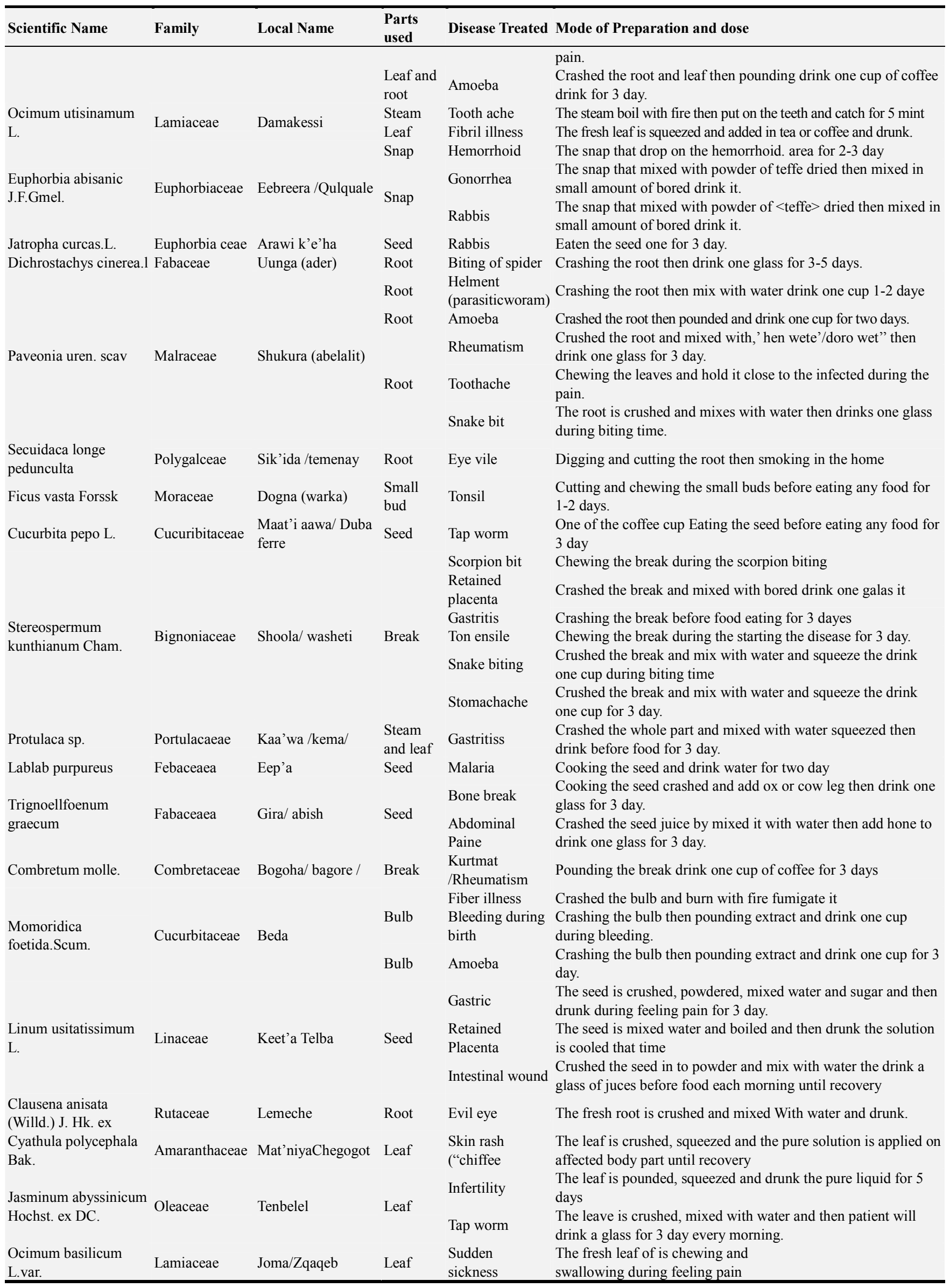




\begin{tabular}{|c|c|c|c|c|c|}
\hline Scientific Name & Family & Local Name & $\begin{array}{l}\text { Parts } \\
\text { used }\end{array}$ & Disease Treated & Mode of Preparation and dose \\
\hline Tamarindus indica L. & Fabaceae & $\begin{array}{l}\text { Aabay guutsa } \\
\text { /Mserech }\end{array}$ & Leaf & Wound & $\begin{array}{l}\text { The leaf with Croton macrostachyus is pounded, powdered and } \\
\text { applied on the wounded parts for } 3 \text { day. }\end{array}$ \\
\hline Rumex abyssinicus & Polygonaceae & $\begin{array}{l}\text { Ambat'a } \\
\text { /mokemoko }\end{array}$ & Root & hypertension & $\begin{array}{l}\text { The root of Rumex abyssinicus is pounded, powdered, mixed } \\
\text { with solution of Citrus limon and creamed on affected part } \\
\text { Crushed the root in to powder mix with the bulb of allium } \\
\text { staivum add the mixture into the boiled water and dink the hot } \\
\text { decoction into a cup for } 3 \text { day. }\end{array}$ \\
\hline $\begin{array}{l}\text { Asparagus africanus } \\
\text { Lam }\end{array}$ & Asparagaceae & Eliyia Yeset keset & Root & $\begin{array}{l}\text { Retain of } \\
\text { placenta }\end{array}$ & $\begin{array}{l}\text { Crashed the root and pounding then extract and drink one galas } \\
\text { during this time }\end{array}$ \\
\hline $\begin{array}{l}\text { Anogeissus leiocarpa } \\
\text { Guill. And Perr. }\end{array}$ & Combretaceae & Anususa/ Kerkera & $\begin{array}{l}\text { Root } \\
\text { Break }\end{array}$ & $\begin{array}{l}\text { Stomachache } \\
\text { Retain of } \\
\text { placenta }\end{array}$ & $\begin{array}{l}\text { The root is chewing and swallowing } \\
\text { Crashed the break and pounding then extract and drink one } \\
\text { galas during this time }\end{array}$ \\
\hline Allium cepa L. & Alliaceae & $\begin{array}{l}\text { Birshnk'urat'a/Key } \\
\text { shenkrt }\end{array}$ & Bulb & Hypertension & $\begin{array}{l}\text { The blub is crushed and immersed in little water for } 1 \text { day and } \\
\text { then filtrated by clean cloth and drunk before food }\end{array}$ \\
\hline lepidium sativum L. & Brassicaceae & Siimbila/feto & Seed & $\begin{array}{l}\text { Abdominal pain } \\
\text { Ascariasi }\end{array}$ & $\begin{array}{l}\text { Crushed the seed and mix with injera and eating for } 3 \text { dayes } \\
\text { Crushed the seed then drink one cup for one day. }\end{array}$ \\
\hline Pterolobium stellatum & Fabaceae & Kentefa & Leaf & Goiter & $\begin{array}{l}\text { Crushed the leave mixed with butter then the paste and tide it } \\
\text { and cover it for } 5 \text { day. }\end{array}$ \\
\hline Withania somnifera & Somniferaceae & Gizawa & Leaf & $\begin{array}{l}\text { Eye vile } \\
\text { Diarrhea }\end{array}$ & $\begin{array}{l}\text { Smoke the enter body of the patient with dried leaf. } \\
\text { Crashed the leaf and squeezed drink one cup for } 3 \text { day. }\end{array}$ \\
\hline $\begin{array}{l}\text { Syzygium guineense } \\
\text { (Wild.)Benth }\end{array}$ & Bignoniacea & Daak'uwa/Doqema & Leaf & leprosy & Dried leaf powder mixed with honey I applied 3 day. \\
\hline $\begin{array}{l}\text { Oncoba spinosa } \\
\text { Forssk. }\end{array}$ & Flacourtiaceae & Aas’i & Blub & $\begin{array}{l}\text { Wound } \\
\text { Abortion } \\
\text { Retain of } \\
\text { placenta }\end{array}$ & $\begin{array}{l}\text { Crush the bulb the added to the wound for } 3 \text { day. } \\
\text { Crashed the bulb mixed with water and drink one glass for once. } \\
\text { Crashed the bulb mixed with water and drink one glass for once } \\
\text { during the birth. }\end{array}$ \\
\hline $\begin{array}{l}\text { Vernonia } \\
\text { theophrastifolia } \\
\text { Schweinf } \\
\text { ex.Oliv\&Hiern }\end{array}$ & Asteracea & Eegidima & Leaf & Fiber illness & Crushed the leaf then fumigate for 3 day every night. \\
\hline \multirow{2}{*}{$\begin{array}{l}\text { Premna schimperi } \\
\text { Engl. }\end{array}$} & \multirow[t]{2}{*}{ Verbenaceae } & \multirow[t]{2}{*}{ Chocho } & Leaf & $\begin{array}{l}\text { Common cold } \\
\text { Eye disease }\end{array}$ & $\begin{array}{l}\text { The leaf is pounded and sniffed } \\
\text { Squeeze the leaf and drop of the extract on affected eye for } 3 \\
\text { day }\end{array}$ \\
\hline & & & Root & Caught & $\begin{array}{l}\text { The root is pounded, mixed with sour milk or ergo" and boiled } \\
\text { and then drink for } 3 \text { day. }\end{array}$ \\
\hline $\begin{array}{l}\text { Myrsine } \\
\text { melanophloeos }\end{array}$ & Myrsinaceae & Aluwangisha & Root & $\begin{array}{l}\text { Cancer } \\
\text { Snake bit }\end{array}$ & $\begin{array}{l}\text { Crashed the root and mixed with 'bordi' the drink one galas for } \\
3 \text { day. } \\
\text { Crashed the root pounded and drink one galas during biting time }\end{array}$ \\
\hline $\begin{array}{l}\text { Bersema abyssinaca. } \\
\text { Fresen. }\end{array}$ & Melianthaceae & Cho wusa & Break & Snake bit & $\begin{array}{l}\text { Crashed the break pounded and drink one glas during biting } \\
\text { time. }\end{array}$ \\
\hline Celosia trigyna L. & Amaranthaceae & Aamberesha & Seed & Tap worm & $\begin{array}{l}\text { Crashed the seed and make ball size then mixed Lablab } \\
\text { purpureus swallowing } 3 \text { for one day. }\end{array}$ \\
\hline
\end{tabular}

Table 10. Continued.

\begin{tabular}{|c|c|c|c|c|c|c|c|}
\hline Scientific Name & $\begin{array}{l}\text { Route of } \\
\text { application }\end{array}$ & Habit & $\begin{array}{l}\text { Condition of } \\
\text { preparation }\end{array}$ & $\begin{array}{l}\text { Season of } \\
\text { availability }\end{array}$ & Source & Distribution & Collation No. \\
\hline $\begin{array}{l}\text { Acacia abyssinica hochst.ex. } \\
\text { Benth. }\end{array}$ & $\begin{array}{l}\text { Nostril } \\
\text { Fumig ated }\end{array}$ & Tree & Fresh & Both & Wild & Com & $\mathrm{Ab} / 022$ \\
\hline Allium sativum L. & $\begin{array}{l}\text { Oral } \\
\text { Oral nostril } \\
\text { Derma }\end{array}$ & Herb & Fresh & Both & Home & $\mathrm{Co}$ & $\mathrm{AB} / 060$ \\
\hline $\begin{array}{l}\text { Carduus schimperi Sch. Bip. } \\
\text { ex A. Rich }\end{array}$ & $\begin{array}{l}\text { Dermal } \\
\text { Oral } \\
\text { Oral } \\
\text { Oral } \\
\text { Oral }\end{array}$ & Herb & Both & Wet & Wild & Co & $\mathrm{AB} / 021$ \\
\hline Carissa spinarum L. & $\begin{array}{l}\text { Oral } \\
\text { Fumigate } \\
\text { Oral } \\
\text { Oral }\end{array}$ & Shrub & Both & Both & Wild & Medim & $\mathrm{AB} / 002$ \\
\hline
\end{tabular}




\begin{tabular}{|c|c|c|c|c|c|c|c|}
\hline Scientific Name & $\begin{array}{l}\text { Route of } \\
\text { application }\end{array}$ & Habit & $\begin{array}{l}\text { Condition of } \\
\text { preparation }\end{array}$ & $\begin{array}{l}\text { Season of } \\
\text { availability }\end{array}$ & Source & Distribution & Collation No. \\
\hline $\begin{array}{l}\text { Clutia abyssinica Jaub. and } \\
\text { Spach }\end{array}$ & $\begin{array}{l}\text { Fumig ate } \\
\text { Ear } \\
\text { Dermal } \\
\text { Oral }\end{array}$ & Shrub & Both & Both & Wild & Med im & $\mathrm{AB} / 034$ \\
\hline Coffea arabica L. & $\begin{array}{l}\text { Dermal } \\
\text { Oral }\end{array}$ & Shrub & Both & Both & Home garden & Rare & $\mathrm{AB} / 023$ \\
\hline Cordia africana Lam. & $\begin{array}{l}\text { Oral } \\
\text { Oral } \\
\text { Oral } \\
\text { Oral } \\
\text { Oral }\end{array}$ & Tree & Both & Both & Wild & Com & $\mathrm{AB} / 010$ \\
\hline Croton macrostachyus Del. & $\begin{array}{l}\text { Dermal } \\
\text { Fumigate } \\
\text { fumigate } \\
\text { Fumig ate } \\
\text { Oral } \\
\text { Oral } \\
\text { Dermal } \\
\text { Dermal }\end{array}$ & Tree & Both & Both & Wild & Com & $\mathrm{AB} / 028$ \\
\hline Solanu nigrum L. & $\begin{array}{l}\text { Derma } \\
\text { Oral } \\
\text { Oral } \\
\text { Oral }\end{array}$ & Herb & Fresh & Both & Wild & Rare & $\mathrm{AB} / 030$ \\
\hline Datura stramonium L & $\begin{array}{l}\text { Dermal } \\
\text { Derma }\end{array}$ & Herb & Wild & Fresh & Rare & Rare & $\mathrm{AB} / 003$ \\
\hline Eucalyptus globulus Labill, & $\begin{array}{l}\text { Oral } \\
\text { fumigate } \\
\text { Oral }\end{array}$ & Tree & Home & Fresh & Both & Com & $\mathrm{AB} / 056$ \\
\hline $\begin{array}{l}\text { Justicia schimperiana } \\
\text { (Hochst. ex Nees) } \\
\text { T. Anders. }\end{array}$ & $\begin{array}{l}\text { Oral } \\
\text { Oral } \\
\text { Oral and derma } \\
\text { Oral } \\
\text { Oral } \\
\text { Oral } \\
\text { Oral }\end{array}$ & Shrub & Wild & Fresh & Both & Med & $\mathrm{AB} / 031$ \\
\hline Ficus sur Forssk.,. & Oral & Tree & Wild & Fresh & Both & Rare & $\mathrm{AB} / 054$ \\
\hline $\begin{array}{l}\text { Lagenaria siceraria (Mol.) } \\
\text { Standl }\end{array}$ & Oral & Climber & Home garden & Fresh & Wet & Medium & $\mathrm{AB} / 057$ \\
\hline Ximenia caffra. Sond., & $\begin{array}{l}\text { Dermal } \\
\text { Oral } \\
\text { Oral }\end{array}$ & Shrub & Forest & Wild & Both & Rear & $\mathrm{AB} / 055$ \\
\hline Melia azedarach L. & $\begin{array}{l}\text { Oral } \\
\text { Oral }\end{array}$ & Tree & Home & Fresh & Both & Com & $\mathrm{AB} / 007$ \\
\hline Nicotiana tabacum L. & $\begin{array}{l}\text { Oral } \\
\text { Oral }\end{array}$ & Herb & Home & Both & Both & Rear & $\mathrm{AB} / 058$ \\
\hline $\begin{array}{l}\text { Catha edulis } \\
\text { (Vahal.Forssk.ex.Endl. }\end{array}$ & $\begin{array}{l}\text { Oral } \\
\text { Oral } \\
\text { Nasal }\end{array}$ & Shrub & Home garden & Fresh And dry & Both & Medium & $\mathrm{AB} / 053$ \\
\hline Ruta chalepensis L. & $\begin{array}{l}\text { Oral } \\
\text { Nasal }\end{array}$ & Herb & Home & Fresh & Wet & Med & $\mathrm{AB} / 004$ \\
\hline $\begin{array}{l}\text { Sida schimperi Hochst. ex. } \\
\text { A. Rich }\end{array}$ & $\begin{array}{l}\text { Dermal } \\
\text { Oral }\end{array}$ & Herb & Wild & Fresh & Both & Rare & $\mathrm{AB} / 006$ \\
\hline Vernonia amygdalina Del & $\begin{array}{l}\text { Dermal } \\
\text { Fumigant } \\
\text { Oral } \\
\text { Oral } \\
\text { Dermal } \\
\text { Derma }\end{array}$ & Shrub & Wild & Fresh & Both & Medium & $\mathrm{AB} / 018$ \\
\hline Combretum collinum & $\begin{array}{l}\text { Oral } \\
\text { Fumigate } \\
\text { Burn } \\
\text { Oral }\end{array}$ & Tree & Wild & Fresh & Both & Rare & $\mathrm{AB} / 008$ \\
\hline Kalancheo petitiana A.Rich, & $\begin{array}{l}\text { Ear } \\
\text { Dermal } \\
\text { Oral } \\
\text { Oral }\end{array}$ & Herb & Wild & Fresh & Wet & Rear & $\mathrm{AB} /$ \\
\hline
\end{tabular}




\begin{tabular}{|c|c|c|c|c|c|c|c|}
\hline Scientific Name & $\begin{array}{l}\text { Route of } \\
\text { application }\end{array}$ & Habit & $\begin{array}{l}\text { Condition of } \\
\text { preparation }\end{array}$ & $\begin{array}{l}\text { Season of } \\
\text { availability }\end{array}$ & Source & Distribution & Collation No. \\
\hline Rehamnus prinoides L. Herit & $\begin{array}{l}\text { Oral } \\
\text { Oral }\end{array}$ & Shrub & Home & Both & Both & Rare & $\mathrm{AB} / 025$ \\
\hline Zingiber officinale Roscoe, & $\begin{array}{l}\text { Oral } \\
\text { Oral }\end{array}$ & Herb & Home & Both & Both & Rare & $\mathrm{AB} / 048$ \\
\hline $\begin{array}{l}\text { Clematis hirsuta perr and } \\
\text { Guill }\end{array}$ & $\begin{array}{l}\text { Dermal } \\
\text { Tooth surfac } \\
\text { Nasal } \\
\text { Oral }\end{array}$ & Climber & Wild & Fresh & Wet & Rare & $\mathrm{AB} / 013$ \\
\hline $\begin{array}{l}\text { Gardenia ternifolia } \\
\text { Schumach.\&Thonn., }\end{array}$ & $\begin{array}{l}\text { Nasally } \\
\text { Oral } \\
\text { Oral } \\
\text { Oral }\end{array}$ & Shrub & Wild & Fresh & Both & Rare & $\mathrm{AB} / 012$ \\
\hline Ocimum utisinamum L. & $\begin{array}{l}\text { Oral } \\
\text { Oral \& fumigate } \\
\text { dermal }\end{array}$ & Shru & Home & Fresh & Both & $\mathrm{Me}$ & $\mathrm{AB} / 061$ \\
\hline Jatropha curcas.L. & Oral & Shrub & Home & Dry fresh & Both & Mediu & $\mathrm{AB} / 051$ \\
\hline Dichrostachys cinerea.1 & Oral & Shrub & Wild & Fresh & Both & Rear & $\mathrm{AB} / 014$ \\
\hline Paveonia uren. scav & $\begin{array}{l}\text { Oral } \\
\text { Oral } \\
\text { Oral } \\
\text { Oral } \\
\text { Oral }\end{array}$ & Climber & Wild & Fresh & Wet & Rare & $\mathrm{AB} / 040$ \\
\hline Secuidaca longe pedunculta & Fumigate & Tree & Wild & Fresh dry & Both & Rare & $\mathrm{AB} / 032$ \\
\hline Ficus vasta Forssk & Oral & Tree & Wild & Fresh & Both & Rear & $\mathrm{AB} / 020$ \\
\hline Cucurbita pepo L. & $\begin{array}{l}\text { Oral } \\
\text { Oral } \\
\text { Oral }\end{array}$ & Climber & Home & Both & Both & medium & $\mathrm{AB} / 049$ \\
\hline $\begin{array}{l}\text { Stereospermum kunthianum } \\
\text { Cham. }\end{array}$ & $\begin{array}{l}\text { Oral } \\
\text { Oral } \\
\text { Oral } \\
\text { Oral }\end{array}$ & Tree & Wild & Fresh & Both & Medium & $\mathrm{AB} / 047$ \\
\hline Protulaca sp. & Oral & Herb & $\begin{array}{l}\text { Home } \\
\text { garden }\end{array}$ & Fresh & Both & Med ium & $\mathrm{AB} / 027$ \\
\hline Lablab purpureus & Oral & Climber & Home garden & Fresh & Wet & Mediu & $\mathrm{AB} / 026$ \\
\hline Trignoellfoenum graecum & $\begin{array}{l}\text { Oral } \\
\text { Oral }\end{array}$ & Herb & $\begin{array}{l}\text { Home } \\
\text { garden }\end{array}$ & Dry & Both & Medium & \\
\hline Combretum molle. & $\begin{array}{l}\text { Oral } \\
\text { Fumig ate }\end{array}$ & Tree & Wild & Fresh & Both & Medium & $\mathrm{AB} / 038$ \\
\hline Momoridica foetida.Scum. & $\begin{array}{l}\text { Oral } \\
\text { Oral }\end{array}$ & Herb & Wild & Fresh & Wet & Rear & $\mathrm{AB} / 059$ \\
\hline Linum usitatissimum L. & $\begin{array}{l}\text { Oral } \\
\text { Oral } \\
\text { Oral }\end{array}$ & Herb & Home garden & Both & Both & Rare & $\mathrm{AB} / 042$ \\
\hline $\begin{array}{l}\text { Clausena anisata (Willd.) J. } \\
\text { Hk. ex }\end{array}$ & Oral & Tree & Wild & Fresh & Both & Rare & \\
\hline Cyathula polycephala Bak. & Dermal & Herb b & Wild & Fresh & Wet & Common & $\mathrm{AB} / 035$ \\
\hline $\begin{array}{l}\text { Jasminum abyssinicum } \\
\text { Hochst. ex DC. }\end{array}$ & Oral & Climber & Wild & Fresh & Both & Rare & $\mathrm{AB} / 001$ \\
\hline Ocimum basilicum L.var. & Oral & Herb & Home garden & Fresh & Wet & Rare & $\mathrm{AB} / 050$ \\
\hline Tamarindus indica L. & Dermal & Shrub & Wild & Fresh & Both & Medium a & $\mathrm{AB} / 041$ \\
\hline Rumex abyssinicus & $\begin{array}{l}\text { Dermal } \\
\text { Oral }\end{array}$ & Herb & Home garden & Dry & Wet & Rear & \\
\hline Asparagus africanus Lam & Oral & Herb & Wild & Fresh & Wet & Rear & $\mathrm{AB} / 033$ \\
\hline $\begin{array}{l}\text { Anogeissus leiocarpa Guill. } \\
\text { And Perr. }\end{array}$ & $\begin{array}{l}\text { Oral } \\
\text { Oral }\end{array}$ & Tree & Wild & Fresh & Both & Rare & $\mathrm{AB} / 009$ \\
\hline Allium cepa L. & Oral & Herb & Home garden & Fresh & Both & Medium & $\mathrm{AB} / 005$ \\
\hline Capparis tomentosa.Lam. & Fumigated & Shrub & Wild & Fresh & Both & Rear & $\mathrm{AB} / 019$ \\
\hline lepidium sativum L. & $\begin{array}{l}\text { Oral } \\
\text { Oral }\end{array}$ & Herb & Home garden & Dry & Both & Rare & \\
\hline Pterolobium stellatum & Tide & shrub & Wild & Fresh & Both & Medium & $\mathrm{AB} / 029$ \\
\hline Withania somnifera & $\begin{array}{l}\text { Fumigated } \\
\text { Oral }\end{array}$ & shrub & Wild & Both & Both & Rare & $\mathrm{AB} / 046$ \\
\hline
\end{tabular}




\begin{tabular}{|c|c|c|c|c|c|c|c|}
\hline Scientific Name & $\begin{array}{l}\text { Route of } \\
\text { application }\end{array}$ & Habit & $\begin{array}{l}\text { Condition of } \\
\text { preparation }\end{array}$ & $\begin{array}{l}\text { Season of } \\
\text { availability }\end{array}$ & Source & Distribution & Collation No. \\
\hline \multicolumn{8}{|l|}{ (Wild.)Benth } \\
\hline Oncoba spinosa Forssk. & $\begin{array}{l}\text { Dermal } \\
\text { Oral } \\
\text { Oral }\end{array}$ & Herb & Wild $\mathrm{t}$ & Fresh & Wet & Rear & $\mathrm{AB} / 048$ \\
\hline $\begin{array}{l}\text { Vernonia theophrastifolia } \\
\text { Schweinf ex.Oliv\&Hiern }\end{array}$ & fumigate & Shrub & Wild & Fresh & both & common & $\mathrm{AB} / 048$ \\
\hline Dicrocephale latifolia & Oral & Herb & Fresh & Wild & Wet & $\mathrm{Co}$ & $\mathrm{AB} / 052$ \\
\hline $\begin{array}{l}\text { Breonadia salicina } \\
\text { (Vahl.Heppehr\&wood }\end{array}$ & Dermal & Tree & Fresh & Wild & Both & Rare & $\mathrm{AB} / 024$ \\
\hline Premna schimperi Engl. & $\begin{array}{l}\text { Nasal } \\
\text { Dermal } \\
\text { Oral }\end{array}$ & Shrub & Fresh & Wild & Both & Rare & $\mathrm{AB} / 044$ \\
\hline Myrsine melanophloeos & $\begin{array}{l}\text { Oral } \\
\text { Oral }\end{array}$ & Tree & Fresh & Wild & Both & Rare & $\mathrm{AB} / 017$ \\
\hline Bersema abyssinaca. Fresen. & Oral & Shrub & Fresh & Wild & Both & Rare & $\mathrm{AB} / 044$ \\
\hline Celosia trigyna L. & Oral & Herb & Fresh & Wild & Both & Rare & \\
\hline
\end{tabular}

Key: $(\mathrm{Hb}=$ Habit, $\mathrm{Pu}=$ Parts used, $\mathrm{Ut}=\mathrm{Used}$ to treat, $\mathrm{Cp}=$ Condition of preparation, $\mathrm{Ra}=$ Route of application, $\mathrm{T}=\mathrm{Tree}, \mathrm{H}=\mathrm{Herb}, \mathrm{Sh}=\mathrm{Shrub}, \mathrm{Cl}=\mathrm{Climber}, \mathrm{F}=\mathrm{Fresh}$, $\mathrm{D}=$ Dried, F/D=Fresh/Dried, $\mathrm{O}=$ Oral, Dm=Dermal, Na=Nasal, Er=Ear, L=Leaf, Rt=Root, St=Stem, Ba=Bark, Fr=Fruit, S=Seed, Bu=Bulb, La=Latex, $\mathrm{Ds}=$ Distribution, $\mathrm{C}=$ Common, $\mathrm{M}=$ Medium $\mathrm{R}=$ Rare, Sa Season of ability, $\mathrm{W}=$ Wet= $=\mathrm{D}=\mathrm{Dry}=\mathrm{B}=$ Both season.

Table 11. Lists of medicinal plants used to treat livestock ailments in the Dibati woreda by shinasha people.

\begin{tabular}{|c|c|c|c|c|c|}
\hline Scientific Name & Family & Local Name & $\begin{array}{l}\text { Part of } \\
\text { used }\end{array}$ & $\begin{array}{l}\text { Disease } \\
\text { treated }\end{array}$ & Mode of preparation and dose \\
\hline Rhamnus Prinoides & Rhamnaceae & Gesho & Leaf & Leech & $\begin{array}{l}\text { The fresh leaf of Rhamnus Prinoides is pounded, squeezed and } \\
\text { added few in the mouth for one day in morning. }\end{array}$ \\
\hline Ficus vasta Forssk & Moraceae & Doogina/warka & leaf & Wound & $\begin{array}{l}\text { The fresh leaf of Ficus vasta is pounded, squeezed and creamed the } \\
\text { affected part. }\end{array}$ \\
\hline $\begin{array}{l}\text { Anarrhinum } \\
\text { forskaorlii }\end{array}$ & Scrophlariaceae & Shukura & Whole parts & Coccidiosis & $\begin{array}{l}\text { The whole parts Anarrhinum forskaorlii expect roots with } \\
\text { Allium sativum is pounded and immersed for } 1 \text { days and drunk }\end{array}$ \\
\hline $\begin{array}{l}\text { Grewia ferruginea } \\
\text { Juss. }\end{array}$ & Tilaceae & K'oriya & Leaf & $\begin{array}{l}\text { Retained } \\
\text { placenta } \\
\text { Bloating }\end{array}$ & $\begin{array}{l}\text { The fresh leaf of Grewia ferruginea is pounded, squeezed and drunk } \\
\text { Crashed leaf mixed with water and salt drink it }\end{array}$ \\
\hline Nicotiana tabacum.L & Solanaceae & Tumbaka Timbaho & Leaf & Leech & $\begin{array}{l}\text { Crush dry leaves mix with water and give it to cattle as drink one } \\
\text { galas morning }\end{array}$ \\
\hline $\begin{array}{l}\text { Justicia } \\
\text { schimperianaT.Anders. }\end{array}$ & Acanthaceae & Simiza & Root & $\begin{array}{l}\text { Rabbis } \\
\text { Coccidiosis }\end{array}$ & $\begin{array}{l}\text { Crushed the root then drink one cup for 2-3 day. } \\
\text { The root crushed then mixed with water and drinking morning for } 3 \text { day. }\end{array}$ \\
\hline Melia azedarach & Meliaceae & Mimiya & Leaf & $\begin{array}{l}\text { White } \\
\text { cholera } \\
\text { New castle }\end{array}$ & $\begin{array}{l}\text { The leaf crushed then mixed with water drink during morning time } \\
\text { for } 3 \text { day. } \\
\text { The leaf is crushed then mixed with water and drink oral }\end{array}$ \\
\hline Cucurbita pepo.L & Cucuribitaceae & $\begin{array}{l}\text { Maat'i aawa Duba } \\
\text { fere }\end{array}$ & $\begin{array}{l}\text { Leaf and } \\
\text { climber }\end{array}$ & Bloating & $\begin{array}{l}\text { The leaf and climber is burn then mixed with water and extract } \\
\text { drinking before eating any grass for 2-3 day. }\end{array}$ \\
\hline $\begin{array}{l}\text { Myrsine } \\
\text { melanophloeos }\end{array}$ & Myrsinaceae & Aalwangisha & Leaf & Black leg & The fresh leaf is fumigated in dry place for 3-5 day. \\
\hline $\begin{array}{l}\text { Asparagus africanus } \\
\text { Lam. }\end{array}$ & Asparagaceae & Eliyia Yeset keset & Root & $\begin{array}{l}\text { Retain of } \\
\text { placenta }\end{array}$ & $\begin{array}{l}\text { Crashed the bulb mixed with water and drink one glass for once } \\
\text { during the birth time. }\end{array}$ \\
\hline Cordia africana Lam. & Boraginaceae & Baanja/ Waza & $\begin{array}{l}\text { Break } \\
\text { Break }\end{array}$ & $\begin{array}{l}\text { Diarrhea } \\
\text { Eye disease }\end{array}$ & $\begin{array}{l}\text { Crushed the break then mixed with salt then drink one glas for } 3 \text { day. } \\
\text { Crushed the break and mixed with duba fere pounded and washed } \\
\text { the eye for } 3 \text { day. }\end{array}$ \\
\hline & & & Root & cough & $\begin{array}{l}\text { Crushed the root and mixed with water egg then drink one galas for } \\
3 \text { day. }\end{array}$ \\
\hline $\begin{array}{l}\text { Carduus schimperi } \\
\text { Sch. }\end{array}$ & Asteraceae & Kooshoshila & Leaf & Mouth rash & $\begin{array}{l}\text { The leaf burn then ash can mix with butter washed that mouth rash } \\
\text { for } 3 \text { day. }\end{array}$ \\
\hline $\begin{array}{l}\text { Euphorbia ampliphylla } \\
\text { J.F.Gmel }\end{array}$ & Euphorbiaceae & $\begin{array}{l}\text { Eebreer } \\
\text { a/Qulquale }\end{array}$ & Snap & Rabbis & $\begin{array}{l}\text { The snap is mixed with teffe bread and salt then pounded and eaten } \\
\text { for } 3 \text { day morning before eating any grass. }\end{array}$ \\
\hline $\begin{array}{l}\text { Clutia abyssinica Jaub. } \\
\text { and Spach }\end{array}$ & Euphorbiaceae & Batska/feyele feg & Leaf & $\begin{array}{l}\text { Diarrhea } \\
\text { with blood }\end{array}$ & $\begin{array}{l}\text { The leaf is crushed and mixed with salt and drink one glass for } 3 \\
\text { day }\end{array}$ \\
\hline lepidium sativum $\mathrm{L}$. & Brassicaceae & Siimbila/feto & Seed & Bloating & The seed crushed and mixed with water then drink one glass for 3 day. \\
\hline $\begin{array}{l}\text { Clausena anisata } \\
\text { (Willd) Beth. }\end{array}$ & Rutaceae & Lemich & Leaf & Coccidiosis & The leaf is crushed then mixed with water and given oral for the hen \\
\hline $\begin{array}{l}\text { Gardenia ternifolia } \\
\text { Fresen. }\end{array}$ & Rubibaceaea & Gaaba /Gambilo & Root & Eye of cow & $\begin{array}{l}\text { Crushed the root and mixed with duba fere pounded and washed the } \\
\text { eye for } 3 \text { day. }\end{array}$ \\
\hline
\end{tabular}


Table 11. Continued.

\begin{tabular}{|c|c|c|c|c|c|c|c|}
\hline Scientific Name & $\begin{array}{l}\text { Rout of } \\
\text { application }\end{array}$ & Habit & $\begin{array}{l}\text { Condition of } \\
\text { preparation }\end{array}$ & $\begin{array}{l}\text { Season of } \\
\text { availability }\end{array}$ & Habitat & Distribution & $\begin{array}{l}\text { Collation } \\
\text { No. } \\
\end{array}$ \\
\hline Rhamnus Prinoides & Oral & Shrub & Fresh & Both & Wild & Medi & $\mathrm{AB} / 025$ \\
\hline Ficus vasta Forssk & Derma 1 & Tree & fresh & Both & Wild & Rare & $\mathrm{AB} / 020$ \\
\hline Anarrhinum forskaorlii & Oral & Herb & Fresh & Wet & Wild & Rare & $\mathrm{AB} / 040$ \\
\hline Grewia ferruginea Juss. & $\begin{array}{l}\text { Oral } \\
\text { Oral }\end{array}$ & Tree & Fresh & Both & Wild & Rear & \\
\hline Nicotiana tabacum.L & Oral & Herb & Both & Both & Home & Medium & $\mathrm{AB} / 058$ \\
\hline Melia azedarach & $\begin{array}{l}\text { Oral } \\
\text { Oral }\end{array}$ & Tree & Fresh & Both & Wild & Medium & $\mathrm{AB} / 007$ \\
\hline Cucurbita pepo.L & Oral & Climber & Fresh & Both & Home & Medium & $\mathrm{AB} / 049$ \\
\hline Myrsine melanophloeos & Fumigated & Tree & Fresh & Both & Wild & Rare & $\mathrm{AB} / 017$ \\
\hline Asparagus africanus Lam. & Oral & Herb & Fresh & Wet & Wild & Rare & $\mathrm{AB} / 033$ \\
\hline Cordia africana Lam. & $\begin{array}{l}\text { Oral } \\
\text { Dermal } \\
\text { Oral }\end{array}$ & Tree & Fresh & Both & Willd & Medium & $\mathrm{AB} / 010$ \\
\hline Carduus schimperi Sch. & Dermal & Herb & Fresh & Wet & wild & Rear & $\mathrm{AB} / 021$ \\
\hline Euphorbia ampliphylla J.F.Gmel & Oral & Shrub & Fresh & Both & Home & Rear & PHOTO \\
\hline Clutia abyssinica Jaub. and Spach & Oral & shrub & Fresh & Both & Home & Medium & $\mathrm{AB} / 034$ \\
\hline lepidium sativum L. & Oral & Herb & Dry & Wet & Hom & Rare & $\mathrm{AB} / 61$ \\
\hline Clausena anisata (Willd) Beth. & Oral & Tree & Fresh & Both & Wild & Rare & $\mathrm{AB} / 65$ \\
\hline Gardenia ternifolia Fresen. & Dermal & Shrub & Fresh & Both & Wild & Medium & $\mathrm{AB} / 012$ \\
\hline
\end{tabular}

Key: $(\mathrm{Hb}=$ Habit, $\mathrm{Pu}=$ Parts used, $\mathrm{Ut}=\mathrm{Used}$ to treat, $\mathrm{Cp}=$ Condition of preparation, $\mathrm{Ra}=$ Route of application, $\mathrm{T}=\mathrm{Tree}, \mathrm{H}=\mathrm{Herb}, \mathrm{Sh}=\mathrm{Shrub}, \mathrm{Cl}=\mathrm{Climber}, \mathrm{F}=\mathrm{Fresh}$, $\mathrm{D}=$ Dried, $\mathrm{F} / \mathrm{D}=$ Fresh/Dried, $\mathrm{O}=$ Oral, Dm=Dermal, Na=Nasal Er=Ear, L=Leaf, Rt=Root, St=Stem, Ba=Bark, $\mathrm{S}=\mathrm{Seed}, \mathrm{Bu}=\mathrm{Bulb}, \mathrm{Snap}, \mathrm{SN} \mathrm{Ds}=\mathrm{Distribution}$, $\mathrm{C}=$ Common, $\mathrm{M}=$ Medium $\mathrm{R}=$ Rare, $=$ Season of ability, Wet=Dry=Both season.

\section{References}

[1] Abiyu Enyew, Zemede A, Ensermu K, Raja N (2014). Ethnobotanical Study of TraditionalMedicinal Plants in and Around Fiche District, Central Ethiopia. Current Research Journal of Biological Sciences 6 (4): 154-167. Addis Ababa, Ethiopia, Uppsala Sweden 2009; 8: 1-7.

[2] Addisie. Y, Yared. D, Kumar. PA, Tomas. Z, Awol. A, 2012) Traditional medicinal plant used by people in Libo kemkem district, south Gondar, Ethiopia, Asian j. Agric Sci. 4: 171-171.

[3] Assegid Assefa and Tesfaye Abebe. (2014). Ethnobotanical Study of Wild Medicinal Trees and Shrubs in Benna Tsemay District, Southern Ethiopia. Journal of Science \& Development 2 (1) 17.

[4] Ayeni. E and Basiri B. (2018). Ethnoveterinary Survey of Plants used in Treating Livestock among the Fulani people of Girei, Adamawa State, Nigeria. WNOFNS: 53-66 EISSN 2543-5426.

[5] Balcha Abera (2014). Medicinal plants used in traditional medicine by Oromo people, Ghimbi District, Southwest Ethiopia. Journal of Ethnobiology and Ethnomedicine; 10 (40): 1-15.

[6] Bayafers Tamene (2000). A Floristic Analysis and Ethnobotanical Study of the Semi- Wet land of Cheffa Area, South Wello, Ethiopia. Agriculture and Healthcare: ISSN 2224-3208 (Paper) ISSN 2225-093 Vol. 5, No. 1.

[7] Bizuneh Woldeab, Reta Regassa, Tibebu Alemu, and Moa Megersa (2018). Medicinal Plants Used for Treatment of Diarrhoeal Related Diseases in Ethiopia. Evidence-Based Complementary and Alternative Medicine Volume Article ID4630371, 20 pages https://doi.org/10.1155/2018/4630371

[8] Cotton, C. M., 1996. Ethnobotany: Principles and Applications. John Willey and Sons LTD. Chichester, UK, pp. 424.

[9] Endalew Amenu (2007). Use and Management of Medicinal Plants by indigenous People of Ejaji Area (Chelya Wereda) West Shewa, Ethiopia: An Ethnobotanical Approach, M.Sc Thesis. Addis Ababa Ethiopia.

[10] Endeshaw Bekele (2007): study on actual situation of mechanical plants in Ethiopia prepared for Japan association for international collaboration of agriculature and forestry.

[11] Ermias Lulekal, Ensermu Kelbessa, Tamrat Bekele and Haile Yineger (2008). Plant Species Composition and Structure of the Mana Angetu Moist Montane Forest, South-Eastern Ethiopia. Journal of East African Natural History, 97: 165185.

[12] Fisseha Mesfin (2007). An Ethnobotanical Study of Medicinal Plants in Wonago Wereda, SNNPR, Ethiopia, M.Sc. Thesis. Addis Ababa University, Addis Ababa. Ethiopia.

[13] Getnet Chokole, Zemede A, Ensermu K (2015). Ethnobotanical study of medicinal plants in the environs of Tara-gedam and Amba remnant forests of Libo Kemkem District, northwest Ethiopia. Journal of Ethnobiology and Ethnomedicine. 2015; 11 (4): 1-38.

[14] Getnet Chekol (2017). Ethnobotanical study of medicinal plants used against human ailments in Gubalafto District, Northern Ethiopia. Journal of Ethnobiology and Ethnomedicine. 13:55.

[15] Gidey Yirga (2010). Use of traditional medicinal plants by indigenous people in Mekele town, capital city of Tigray regional state of Ethiopia, Journal of Medicinal Plants Research 4: 25-50. 
[16] Haile Yineger and Dilnessaw Yewhalaw (2007). Traditional medicinal plant knowledge and use by local healers in Sekoru District, Jimma Zone, Southwestern Ethiopia. Journal of Ethnobiology and Ethnomedicine. 3: 24-26.

[17] Haile Yineger, Ensermu Kelbessa, Tamrat Bekele and Ermias Lulekal, (2008). Plants Used in Traditional Management of Human Ailments at Bale Mountain National Park, Southeastern Ethiopia. J. Med. Plant. Res. 2 (6): 132-153.

[18] Kebu Balemie, Ensermu Kelbessa and Zemede Asfaw., (2004). Indigenous medicinal plant utilization, management and threats in Fentalle area, Eastern Shewa, Ethiopia. Ethiopian Journal Biological Scince, 3: 37-58.

[19] Luiz. R. Saldanha. G., Reinaldo, F., Paiva de A. (2005). Knowledge and use of medicinal plants by local specialist in a region of Atlantic Forest in the state of Pernambuco (North eastern Brazil).

[20] Martine G (1995). Ethnobotany: A method of manual Chopman and Hall London UK. Grat Britain University Press e Cambridg press p 267. May 1998, IBCR, Addis Ababa, Ethiopia.

[21] Meaza G, Tadesse B, Maria AS, Piero B, Gidey Y. (2015). Traditional medicinal plants used by Kunama ethnic group in Northern Ethiopia. Journal of Medicinal Plants Research.; 9 (15): 494-509.

[22] Mirutse Giday, Tilahun Teklehaymanot, Abebe Animut, and Yalemtsehay Mekonn (2007). Medicinal plants of the Shinasha, Agew-awi and Amhara peoples in northwest Ethiopia. Journal of Ethnopharmacology 110: 516-525.

[23] Moa Megersa (2010) Ethnobotanical Study of Medicinal Plants in Wayu Tuka Wereda, East Wollega Zone of Oromia Region,. MSC Thesis Addis Ababa, Ethioipa.

[24] Mulugeta Kebebew (2016). Knowledge of medicinal plants used in and around Fincha'a Town, Western Ethiopia. Journal of Pharmacognosy and Phytochemistry; 5 (6): 110-114.

[25] N. Amsalu, Z. Asfaw, and E. Kelbessa, (2015) “An ethnobotanical study of medicinal plants in Farta District, South Gondar Zone of Amhara Region, Ethiopia," pp. 28-55, Haddis Alemayehu Institute of Cultural Studies.

[26] Nigatu Tuasha, Beyene Petros and Zemede Asfaw (2018). Medicinal plants used by traditional healers to treat malignancies and other human ailments in Dalle District, Sidama Zone, Ethiopia. Journal of Ethnobiology and Ethnomedicine: 14: 15-22.

[27] Nigussie Amsalu, Yilkal Bezie, Mulugeta Fentahun, Addisu Alemayehu, and Gashaw Amsalu (2018). Use and Conservation of Medicinal Plants by Indigenous People of Gozamin Wereda, East Gojjam Zone of Amhara Region, Ethiopia: Article ID 2973513, 23 pages https://doi.org/10.1155/2018/2973513
[28] Tadesse Birhanu, Dereje Abera and Eyasu Ejeta (2015). Ethnobotanical Study of Medicinal Plants in Selected Horro Gudurru Woredas, Western Ethiopia., Journal of Biology, Agriculture and Healthcare: ISSN 2224-3208 (Paper) ISSN 2225-093X (Online) Vol. 5, No. 1.

[29] Tafesse Mesfine and Mekonnen Lemma (2001), the role of traditional veterinary Herbal medicinal and its constraints in the animal health care system in Ethiopia, Addis Ababa Ethiopia.

[30] Teferi Flatie, Teferi Gedif, Kaleab Asres and Tsige GebreMariam (2009). Ethnomedical survey of Berta ethnic group Assosa Zone, Benishangul-Gumuz regional state, mid-west Ethiopia. Journal of Ethnobiology and Ethnomedicine 5: 14.

[31] Tena Regasa, (2015). Vascular plant diversity and ethnobotanical study of medicinal and wild edible plants in Jibat, Gedo and Chilimo forests, West Shewa Zone of Oromia Region, Ethiopia, PhD Dissertation, Addis Ababa, Ethiopia.

[32] Tesfaye Hailemariam, Sebsebe Demissew and Zemede Asfaw (2009). An ethnobotanical study of medicinal plants used by local people in the lowlands of Konta Special Woreda, southern nations, nationalities and peoples regional state, Ethiopia. Journal of Ethnobiology and Ethnomedicine, 5: 26.

[33] Teshale Sori, Merga Bekana, Girma Adugna and Ensermu Kelbessa, (2004). Medicinal Plants in the Ethnoveterinary Practices of Borana Pastoralists, Southern Ethiopia; International Journal Applied Research Veternerian Medicine, 2: $220-225$.

[34] Tizazu Gebre (2005). An Ethnobotanical Study of Medicinal Plants in Konso Special Woreda, Southern Nations, and Nationalities and Peoples Regional State, Ethiopia. M.sc. Thesis. Addis Ababa University.

[35] Yamane T (1967) Statics, An Introduction Analysis, 2nd Ed., New York: Harper and Row.

[36] Yihenew Simegniew Birhan, Sintayehu Leshe Kitaw, Yihalem Abebe Alemayehu, Nakachew Minuye Mengesha (2018), Ethnobotanical study of medicinal plants used to treat human diseases in Enarj Enawga District, East Gojjam Zone, Amhara Region, Ethiopia. SM J Med Plant Stud.; 2(1): 1006.

[37] Zemede Asfaw (2001). The role of home gardens in production and conservation of medicinal plants. In: Conservation and Sustainable Use of Medicinal Plants in Ethiopia, Proceeding of The National Work Shop on Biodiversity and Sustainable use of Medicinal Plants In Ethiopia, 2.

[38] Zerhiun W, Mesfin T (1990). The Status of the Vegetation in the Lake region of the Rift Valley of Ethiopia and Possibilities of its Recovery. SINET: Eth. J. Sci., 392: 97-120. 